\title{
A Preliminary Synthesis of Modeled Climate Change Impacts on U.S. Regional Ozone Concentrations
}

\section{Citation}

Weaver, C. P., E. Cooter, R. Gilliam, A. Gilliland, A. Grambsch, D. Grano, B. Hemming, et al. 2009. "A Preliminary Synthesis of Modeled Climate Change Impacts on U.S.

Regional Ozone Concentrations." Bull. Amer. Meteor. Soc. 90 (12) (December): 1843-1863. doi:10.1175/2009bams2568.1.

\section{Published Version}

doi:10.1175/2009BAMS2568.1

\section{Permanent link}

http://nrs.harvard.edu/urn-3:HUL.InstRepos:14764381

\section{Terms of Use}

This article was downloaded from Harvard University's DASH repository, and is made available under the terms and conditions applicable to Other Posted Material, as set forth at http:// nrs.harvard.edu/urn-3:HUL.InstRepos:dash.current.terms-of-use\#LAA

\section{Share Your Story}

The Harvard community has made this article openly available.

Please share how this access benefits you. Submit a story.

Accessibility 


\section{A PRELIMINARY SYNTHESIS OF MODELED CLIMATE CHANGE IMPACTS ON U.S. REGIONAL OZONE CONCENTRATIONS}

by C. P. Weaver, X.-Z. Liang, J. Zhu, P. J. Adams, P. Amar, J. Avise, M. Caughey, J. Chen, R. C. Cohen, E. Cooter, J. P. Dawson, R. Gilliam, A. Gilliland, A. H. Goldstein, A. Grambsch, D. Grano, A. Guenther, W. I. Gustafson, R. A. Harley, S. He, B. Hemming, C. Hogrefe, H.-C. Huang, S. W. Hunt, D. J. Jacob, P. L. Kinney, K. Kunkel, J.-F. Lamarque, B. Lamb, N. K. Larkin, L. R. Leung, K.-J. Liao, J.-T. Lin, B. H. Lynn, K. Manomaiphiboon, C. Mass, D. McKenzie, L. J. Mickley, S. M. O’Neill, C. Nolte, S. N. Pandis, P. N. Racherla, C. Rosenzweig, A. G. Russell, E. Salathé, A. L. Steiner, E. Tagaris, Z. Tao, S. Tonse, C. Wiedinmyer, A. Williams, D. A. Winner, J.-H. Woo, S. Wu, and D. J. Wuebbles

With harmful ozone concentrations tied to meteorological conditions, EPA investigates the U.S. air quality implications of a changing climate.

D iscussion of the potential sensitivity of air quality to climate change has increased in recent years. In 2001, the NRC (acronyms defined in Table 1) posed the question "to what extent will the United States be in control of its own air quality in the coming decades?" noting that "... changing climatic conditions could significantly affect the air quality in some regions of the United States ..." and called for the expansion of air quality studies to include investigation of how U.S. air quality is affected by long-term climatic changes (NRC 2001). A subsequent NRC report emphasized that the U.S. air quality management system must be "flexible and vigilant" to ensure the effectiveness of pollution mitigation strategies in the face of climate change (NRC 2004). The recent IPCC Fourth Assessment Report warned of the possibility of significant air quality degradation in some regions as a result of climate-related changes in the dispersion rate of pollutants, the chemical environment for $\mathrm{O}_{3}$ and aerosol generation, and the strength of emissions from the biosphere, fires, and dust (Solomon et al. 2007).

The mission of the EPA is to protect human health and the environment. To achieve this mission, the EPA implements a variety of programs under the
Clean Air Act that reduces ambient concentrations of air pollutants. Pollutants such as $\mathrm{O}_{3}$ are not emitted directly into the atmosphere; instead, they are created by chemical reactions between $\mathrm{NO}_{\mathrm{x}}$ and VOCs in the presence of heat and sunlight. These pollutants are emitted from a variety of sources, including motor vehicles, chemical and power plants, refineries, factories, and consumer and commercial products, as well as natural sources, such as vegetation, lightning, and biological processes in the soil. The EPA's efforts have been successful: between 1980 and 2007, emissions of VOCs and $\mathrm{NO}_{\mathrm{x}}$ decreased by $50 \%$ and $39 \%$, respectively, even though the gross domestic product increased $124 \%$, vehicle miles traveled increased 103\% and energy consumption increased $30 \%$ (U.S. EPA 2008). Air pollution, however, including $\mathrm{O}_{3}$ pollution, continues to be a widespread public health and environmental problem in the United States, with peak-level $\mathrm{O}_{3}$ concentrations in numerous counties still exceeding the NAAQS for $\mathrm{O}_{3},{ }^{1}$ and with health effects ranging from increased mortality to chronic effects on respiratory and cardiovascular health (e.g., see Jerrett et al. 2009).

${ }^{1}$ The standard is currently set at $75 \mathrm{ppb}$ for the 8-h NAAQS. 
Significant regional variability already exists in ground-level $\mathrm{O}_{3}$ under current climate. A large body of observational and modeling studies have shown that $\mathrm{O}_{3}$ concentrations tend to be especially high where the emissions of VOCs and $\mathrm{NO}_{\mathrm{x}}$ are also large and that $\mathrm{O}_{3}$ concentraitons increase even more when meteorological conditions most strongly favor net photochemical production-persistent high pressure, stagnant air, lack of convection, clear skies, and warm temperatures (e.g., U.S. EPA 1989; NRC 1991; Cox and Chu 1993; Bloomfield et al. 1996; Morris et al. 1995; Sillman and Samson 1995; U.S. EPA 1999; Thompson et al. 2001; Camalier et al. 2007; among many others). Consequently, the $\mathrm{O}_{3}$ NAAQS are most often exceeded during summertime hot spells in places with large natural or anthropogenic precursor emissions (e.g., cities and suburban areas). Table 2 highlights a number of key meteorology-related factors.

Because climate change may alter weather patterns and hence potentially increase the frequency, duration, and intensity of $\mathrm{O}_{3}$ episodes in some regions, it has the potential to create additional challenges for air quality managers. However, the causal chain linking (i) long-term global climate change, (ii) short-term meteorological variability that most directly drives peak $\mathrm{O}_{3}$ episodes, and (iii) $\mathrm{O}_{3}$ changes that ultimately result from the interaction of these meteorological changes with the pollutants present in the environment (which may themselves be sensitive to meteorology) is not straightforward. Changes in the $\mathrm{O}_{3}$ distribution of a given region as a result of climate change will reflect a balance among competing or reinforcing changes in multiple factors. The meteorological variables that affect $\mathrm{O}_{3}$ do not, in general, vary independently of each other, nor must they vary in concert with corresponding effects on $\mathrm{O}_{3}$ concentrations. The $1991 \mathrm{NRC}$ report noted that the relationship between temperature and $\mathrm{O}_{3}$ "cannot readily be extrapolated to a warmer climate because higher temperatures are often correlated empirically with sunlight and meteorology" (NRC 1991). How the relationship between $\mathrm{O}_{3}$ and its meteorological drivers is perceived depends on the timescale considered (see the sidebar on p. 5 for additional information about the temperature- $\mathrm{O}_{3}$ relationship).

In 1999, the EPA ORD Global Change Research Program, in partnership with the EPA OAR, initiated an effort to increase scientific understanding of the multiple complex interactions among climate, emissions, atmospheric chemistry, and air quality. The ultimate goal of this ongoing assessment is to enhance the ability of air quality managers to consider global change in their decisions through improved characterization of the potential effects of global change on air quality, including $\mathrm{O}_{3}, \mathrm{PM}$, and $\mathrm{Hg}$. An integrated assessment framework was designed that leveraged the research and development strengths within both the EPA and the academic research community. This design explicitly recognized the challenges of bridging spatial scales, temporal scales, and disciplines that characterize the global changeregional air quality problem. Consistent with the recommendations of an expert workshop held in 2001 and those of the 2001 NRC report cited earlier
AfFiliations: Weaver, Cooter, Gilliam, Gilliland, Grambsch, Grano, Hemming, Hunt, Nolte, and Winner-U.S. Environmental Protection Agency, Washington, D.C.; Liang, Zhu, M. CaugheY, KUnKel,* LIN,* TAO, Williams, AND WUebbles-University of Illinois at Urbana-Champaign, Urbana, Illinois; AdAMS AND DAWSON-Carnegie Mellon University, Pittsburgh, Pennsylvania; AMAR AND HENortheast States for Coordinated Air Use Management, Boston, Massachusetts; AvISE-California Air Resources Board, Sacramento, California; CHEN-National Research Council Canada, Ottawa, Ontario, Canada; Cohen, Goldstein, Harley, Steiner and TonseUniversity of California, Berkeley, Berkeley, California; GUENTHER, LAMARQUE, AND WIEDINMYER-National Center for Atmospheric Research, Boulder, Colorado; GustAFson AND LeUnG-Pacific Northwest National Laboratory, Richland, Washington; Hogrefe-University at Albany, Albany, New York; HuANG-Science Applications International Corporation, San Diego, California; JACOB, MICKLEY, AND Wu-Harvard University, Cambridge, Massachusetts; KINNEY - Columbia University, New York, New York; LAMB-Washington State University, Pullman, Washington; LARKIN and McKenZIE-U.S. Forest Service Pacific Northwest Research Station, Portland, Oregon; LIAO, MANOMAIPHIBOON, RusSELL, AND
TAGARIS—Georgia Institute of Technology, Atlanta, Georgia; LYNNWeather It Is, Ltd., Efrat, Israel; MASS AND SALATHÉ-University of Washington, Seattle, Washington; O'NeILL-U.S. Department of Agriculture Natural Resources Conservation Service, Portland, Oregon; PANDIS—University of Patras, Rio Patras, Greece; RACHERLA-Foundation for Research and Technology-Hellas, Heraklion, Crete, Greece; RosenzWEIG-National Aeronautics and Space Administration/Goddard Institute for Space Studies, New York, New York; Woo-Konkuk University, Seoul, South Korea *ADDITIONAL AFFILIATIONS: KUNKEL-Desert Research Institute, Reno, Nevada; LIN-Harvard University, Cambridge, Massachusetts

CORRESPONDING AUTHOR: Chris Weaver, U.S. EPA (860I-P), 1200 Pennsylvania Avenue, Washington, DC, 20460.

E-mail: weaver.chris@epamail.epa.gov

The abstract for this article can be found in this issue, following the table of contents.

DOI:10.1175/2009BAMS2568.1

In final form 23 June 2009

(C)2009 American Meteorological Society 
TABLE I. Acronyms used.

\begin{tabular}{|c|c|}
\hline AO & Atmosphere-ocean \\
\hline AQM & Air quality model \\
\hline CB-IV & Carbon Bond Mechanism, version 4.0 \\
\hline CCM3 & Community Climate Model, version 3 \\
\hline CMAQ & Community Multiscale Air Quality \\
\hline CMM5 & University of Illinois Climate Version of Mesoscale Model, version 5 \\
\hline CMU & Carnegie Mellon University \\
\hline $\mathrm{CO}_{2}$ & Carbon dioxide \\
\hline CONUS & Conterminous United States \\
\hline EPA & Environmental Protection Agency \\
\hline GCM & Global climate model \\
\hline GCTM & Global chemistry and transport model \\
\hline GEOS & Goddard Earth Observing System \\
\hline GHG & Greenhouse gases \\
\hline GISS & Goddard Institute for Space Studies \\
\hline GNM & $\begin{array}{l}\text { Georgia Institute of Technology (GIT)-Northeast State for Coordinated Air Use Management (NESCAUM)- } \\
\text { Massachusetts Institute of Technology (MIT) }\end{array}$ \\
\hline $\mathrm{Hg}$ & Mercury \\
\hline IPCC & Intergovernmental Panel on Climate Change \\
\hline JJA & June-August \\
\hline MDA8 & Maximum daily 8 -h average \\
\hline MM5 & Fifth-generation Pennsylvania State University-National Center for Atmospheric Research Mesoscale Model version 5 \\
\hline MOZART & Model for Ozone and Related Chemical Tracers \\
\hline NAAQS & National Ambient Air Quality Standards \\
\hline NCER & National Center for Environmental Research \\
\hline NERL & National Exposure Research Laboratory \\
\hline $\mathrm{NO}_{x}$ & Nitrogen oxides \\
\hline NRC & National Research Council \\
\hline $\mathrm{O}_{3}$ & Ozone \\
\hline OAR & Office of Air and Radiation \\
\hline $\mathrm{OH}$ & Hydroxide \\
\hline ORD & Office of Research and Development \\
\hline PAN & Peroxyacetyl nitrate \\
\hline PCM & Parallel climate model \\
\hline PM & Particulate matter \\
\hline $\mathrm{Ppb}$ & Parts per billion \\
\hline RADM2 & Regional Acid Deposition Model, version 2 \\
\hline $\mathrm{RCM}$ & Regional climate model \\
\hline RAQM & Regional air quality model \\
\hline SAPRC & Statewide Air Pollution Research Center \\
\hline SAQM & SARMAP* Air Quality Model \\
\hline SAT & Surface Air Temperature \\
\hline $\mathrm{SO}_{2}$ & Sulfur dioxide \\
\hline STAR & Science to Achieve Results \\
\hline SRES & Special Report on Emissions Scenarios \\
\hline VOC & Volatile organic compound \\
\hline WSU & Washington State University \\
\hline
\end{tabular}

* SARMAP stands for San Joaquin Valley Air Quality Study (SJVAQS)/Atmospheric Utility Signatures, Predictions, and Experiments (AUSPEX) Regional Model Adaptation Project 
TABLE 2. Meteorological variables with the potential to affect regional air quality (adapted from U.S. EPA 1989).

The average maximum or minimum temperature and/or changes in their spatial distribution and duration, leading to a change in reaction rate coefficients and the solubility of gases in cloud water solution;

The frequency and pattern of cloud cover, leading to a change in reaction rates and rates of conversion of $\mathrm{SO}_{2}$ to acid deposition;

The frequency and intensity of stagnation episodes or a change in the mixing layer, leading to more or less mixing of polluted air with background air;

Background boundary layer concentrations of water vapor, hydrocarbons, $\mathrm{NO}_{x}$, and $\mathrm{O}_{3}$, leading to more or less dilution of polluted air in the boundary layer and altering the chemical transformation rates;

The vegetative and soil emission of hydrocarbons and $\mathrm{NO}_{x}$ that are sensitive to temperature and light levels, leading to changes in their concentrations;

Deposition rates to vegetative surfaces whose absorption of pollutants is a function of moisture, temperature, light intensity, and other factors, leading to changes in concentrations; and

Circulations and precipitation patterns, leading to a change in the abundance of pollutants deposited locally versus those exported off the continent. of pollutant precursors (such as VOCs and $\mathrm{NO}_{\mathrm{x}}$ ), but not changes in anthropogenic emissions of these pollutants (e.g., as a result of future air quality management efforts and/or future economic growth). The second phase, now ongoing, is tackling the additional complexities of integrating the effects of such changes in anthropogenic emissions, in the United States and worldwide, with the climate-only effects investigated in the first phase. The results discussed here are from the first phase only.

The findings synthesized here are taken from several projects carried out by extramural teams funded through the EPA's STAR program within the NCER (visit http://es.epa.gov/ncer/science/ globalclimate/recipients.html) as

(NRC 2001), a major component of the assessment approach is the development and application of global to regional climate and air quality modeling systems. One advantage of the model-based approach underlying the EPA assessment is that integrated climate, meteorology, and air quality modeling systems are capable of capturing a number of these complexities by representing interactions between variables in an internally self-consistent way across multiple space and time scales.

This paper highlights a number of EPA and EPAfunded studies focused on the effect of the impact of climate change on future air quality carried out under this assessment framework. The goal is to provide a preliminary synthesis across the results emerging from these studies, focusing on ground-level $\mathrm{O}_{3}$. An EPA report on the assessment's scientific findings to date and their potential policy relevance provides a broader overview of the assessment as a whole (U.S. EPA 2009). A number of these studies are also highlighted in a recent review (Jacob and Winner 2009).

PARTICIPANTS AND SCOPE. The EPA assessment was designed to be carried out in two phases. In the first phase, modeling systems were used to consider the sensitivity of air quality responses to global climate change alone; this includes direct meteorological effects on atmospheric chemistry and transport and the effect of these meteorological changes on climate-sensitive natural emissions well as from an intramural effort within the EPA's NERL. ${ }^{2}$ Broadly, all of the project teams adapted existing modeling tools as components for assembling their global-to-regional combined climate and air quality modeling systems, including GCTMs, GCMs, RCMs, and RAQMs, along with emissions models and boundary and initial conditions datasets. They applied these modeling systems in numerical experiments designed to investigate the potential sensitivity of U.S. air quality to global climate change, focusing roughly on the 2050s. The modeling approaches taken essentially fall into two categories: (i) investigations of large-scale patterns of climate change effects on U.S. air quality using GCTMs and GCMs alone and (ii) investigations that focus on additional regional details of potential effects using dynamical downscaling with nested RCMs and RAQMs. It is useful to consider both approaches together. The global models simulate the whole world in an internally self-consistent way across both climate and chemistry, but they must use coarse spatial resolution because of computational demand, thereby potentially missing or oversimplifying key processes. Dynamical downscaling increases the resolution, and potentially the realism of important regional processes, but at the expense of introducing lateral boundary conditions into the simulation.

\footnotetext{
${ }^{2} \mathrm{Via}$ an interagency partnership with the National Oceanographic and Atmospheric Administration (NOAA).
} 
Having multiple groups-with differences in emphasis and using a range (albeit still limited) of models, chemical and physical parameterizations, and greenhouse gas scenarios-address the same problem enhances the richness of the EPA assessment effort; the collective results may reveal choices to which the results are particularly sensitive, thereby building insight into the workings of the coupled system. Table 3 provides a summary of the global and regional modeling experiments available to date from this first phase of the assessment, highlighting the different combinations of modeling tools and other aspects of simulation design. Collectively, these simulations (described in more detail in the papers listed in Table 3) represent a large body of information from which to gain insights about the potential effects of global climate change on regional air quality. They are a valuable resource for the climate science, atmospheric chemistry, and air quality management communities.

This paper synthesizes the findings from a subset of these global and regional modeling experiments, focusing on nationwide changes in summertime $\mathrm{O}_{3}$ concentrations due to simulated climate change a few decades into the future. Other pollutants are not addressed here. Most of the experiments focused on summer, as this is the primary season for $\mathrm{O}_{3}$ episodes and exceedances across much of the country.

\section{SYNTHESIS OF MODEL RESULTS. Regional}

modeling results. The principal comparison in this section is across the regional modeling experiments listed in Table 3 that have model domains covering the entire continental United States: these are the NERL, GNM, Illinois 1 and 2, and WSU experiments. The NERL and GNM simulations both relied on the same MM5-downscaled GISS II' GCM climate runs, though GNM simulated three summers compared to five summers for NERL, and they also differed in their development of their emissions inventories. Results from the Berkeley and Columbia simulations, conducted for subsets of the conterminous United States, are referred to in the course of the text to reinforce particular findings. Notice again that the differences in IPCC SRES scenarios for the simula-

\section{THE TEMPERATURE-O $0_{3}$ RELATIONSHIP As Seen From the Perspective of Three Different Time Scales}

EPISODE. The severity of a particular $\mathrm{O}_{3}$ episode lasting one or a few days can depend strongly on temperature. For example, Aw and Kleeman (2003) found that by increasing temperature (but without modifying the other meteorological variables) in an air quality model simulation of a southern California $\mathrm{O}_{3}$ episode, they were able to significantly increase daily peak $\mathrm{O}_{3}$ concentrations. Temperature affects the kinetics of the $\mathrm{O}_{3}$-forming and -destroying chemical reactions. For example, in polluted environments, increasing temperatures will tend to lead to more $\mathrm{NO}_{x}$, and hence more $\mathrm{O}_{3}$, via a decrease in PAN production. Recent EPA STAR-funded results have yielded similar insights for the EPA global change-air quality assessment. Steiner et al. (2006), in a high-resolution simulation of a 5-day $\mathrm{O}_{3}$ episode over California, found that temperature perturbations consistent with plausible 2050s climate change led to increases in afternoon $\mathrm{O}_{3}$ concentrations of $\mathrm{I}-5$ ppb across the state. Dawson et al. (2007), using a different modeling system, found similar effects of temperature modification when simulating $\mathrm{O}_{3}$ concentrations during a weeklong period over the eastern United States.

SEASON. From the perspective of an entire season, however, mean $\mathrm{O}_{3}$ concentration and the number of $\mathrm{O}_{3}$ exceedances will likely depend at least as much on how many of these meteorological episodes that promote $\mathrm{O}_{3}$ formation occur, and how long they last, as on how hot it is during each one. In other words, how often in a given summer that cool, cloudy, rainy, and windy conditions give way to spells of hot, clear, dry, and stagnant conditions will play a large role in determining whether it was a "high $\mathrm{O}_{3}$ " or "low $\mathrm{O}_{3}$ " summer. At this time scale, temperature and $\mathrm{O}_{3}$ will also be positively correlated; however, here the "temperature- $\mathrm{O}_{3}$ " relationship exists at least partly because temperature itself is highly correlated with these other meteorological conditions - such as more sunlight and less ventilation - that also favor increased $\mathrm{O}_{3}$ concentrations.

LONG-TERM CLIMATE CHANGE. On the multidecadal time scales of global climate change, the relationship between temperature and these other meteorological drivers may or may not play out in the same way that is characteristic of seasonal time scales. In some regions, climate change may indeed have the effect of producing long-term average associations between higher temperatures, less cloudiness, and weaker mixing that, in aggregate, would be likely to lead to $\mathrm{O}_{3}$ concentration increases. This would likely be true, for example, in the regions where the IPCC (Solomon et al. 2007) suggests the possibility of increases in the frequency, duration, and intensity of summertime heat waves. In other regions, however, climate change may lead to changes in these other variables that do not favor increases in $\mathrm{O}_{3}$ concentrations. For example, a warmer world is likely, on average, to be a wetter world. Similarly, regions that experience increases in cloudiness (and hence decreases in sunlight and $\mathrm{O}_{3}$ photoproduction) in an altered future climate might have net $\mathrm{O}_{3}$ concentration decreases, despite increased temperatures. 
tions listed in Table 3 refer only to greenhouse gas concentrations and not to precursor pollutants. As emphasized earlier, all of the results shown here are from simulations that held anthropogenic emissions of precursor pollutants constant at present-day levels but allowed climate-sensitive natural emissions of biogenic VOCs to vary in response to the simulated climate changes.

Figure 1 shows summertime mean $\mathrm{MDA}_{8} \mathrm{O}_{3}$ concentration differences between future and present-day climates. This air quality metric is selected because of its direct relevance to U.S. air quality standards. Several key similarities emerge. First, for all the pairs of simulations, substantial regions of the country show increases in $\mathrm{O}_{3}$ concentrations of roughly 2-8 ppb under a future climate. Other regions show little change in $\mathrm{O}_{3}$ concentrations-or even decreases. Importantly, these patterns of climate-induced $\mathrm{O}_{3}$ concentration changes were accentuated in the 95th percentile $\mathrm{MDA} 8 \mathrm{O}_{3}$ compared to the mean $\mathrm{MDA} 8 \mathrm{O}_{3}$, as shown in Fig. 2 for the NERL results. This result, of greater climate sensitivity of $\mathrm{O}_{3}$ at the high end of the $\mathrm{O}_{3}$ distribution, is robust across all of the different modeling groups, as documented in the papers cited. This is significant because it is the high- $\mathrm{O}_{3}$ episodes that most concern air quality managers in the United States.

There are also significant differences, however, in the broad spatial patterns of change simulated by the different modeling groups. For example, the NERL and GNM simulations show increases in $\mathrm{O}_{3}$ concentration in the mid-Atlantic region and parts of the Northeast, Gulf Coast, and parts of the West. They also show decreases in the upper Midwest and Northwest and little change elsewhere, including the Southeast. By contrast, the Illinois-1 experiment shows the strongest increases in the Southeast, the Northwest, and the Mississippi Valley (as well as in

TABLE 3. The climate change-air quality global and regional modeling simulations completed to date as part of the EPA assessment. The SRES scenarios listed refer only to greenhouse gas concentrations, as all simulations discussed below held anthropogenic emissions of $\mathrm{O}_{3}$ precursor pollutants constant between presentday and future simulations. The Illinois-I and $\mathbf{- 2}$ regional and global model runs have identical setups but are driven by the AIFi and the BI SRES greenhouse gas scenarios, respectively. The horizontal grid-cell size listed is that of the air quality simulations, with the exception of the Illinois regional runs, which use $\mathbf{3 0 - k m}$ grid spacing over four subregions of the country and $\mathbf{9 0 - k m}$ everywhere else. For the $\mathrm{O}_{3}$ plots shown

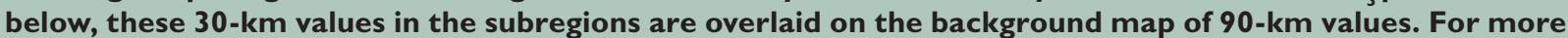
details on GEOS-Chem, see http://homepages.see.leeds.ac.uk/ lecme/GEOS-CHEM. For more details on MOZART, see Horowitz et al. (2003) and http://gctm.acd.ucar.edu/Mozart/models/m4/index.shtml.

\begin{tabular}{|c|c|c|c|c|c|c|c|}
\hline & Berkeley $^{a}$ & Columbiab $^{b}$ & NERLc & GNM $^{d}$ & Illinois Ie & Illinois $^{2 e}$ & WSU' \\
\hline Domain & Central CA & Eastern U.S. & CONUS & CONUS & CONUS & CONUS & CONUS \\
\hline Simulation period & I Aug & $5 \mathrm{JJAs}$ & $5 \mathrm{JJAs}$ & $3 \mathrm{JJAs}$ & I JJA & I JJA & 5 Julys \\
\hline GCM & ССМ3 & GISS AO & GISS II' & GISS II' & PCM & PCM & PCM \\
\hline Global grid & $2.8^{\circ} \times 2.8^{\circ}$ & $4^{\circ} \times 5^{\circ}$ & $4^{\circ} \times 5^{\circ}$ & $4^{\circ} \times 5^{\circ}$ & $2.8^{\circ} \times 2.8^{\circ}$ & $2.8^{\circ} \times 2.8^{\circ}$ & $2.8^{\circ} \times 2.8^{\circ}$ \\
\hline GHG scenario' & $2 \times \mathrm{CO}_{2}$ & $\mathrm{~A} 2$ & Alb & Alb & $\mathrm{AIFi}$ & $\mathrm{BI}$ & $\mathrm{A} 2$ \\
\hline RCM & MM5 & MM5 & MM5 & MM5 & $\mathrm{CMM5}^{2}$ & CMM5 & MM5 \\
\hline Regional grid (km) & 4 & 36 & 36 & 36 & $90 / 30$ & $90 / 30$ & 36 \\
\hline RAQM & $\mathrm{CMAQ}^{3}$ & CMAQ & CMAQ & CMAQ & $\mathrm{AQM}^{4}$ & AQM & CMAQ \\
\hline $\begin{array}{l}\text { Chemical } \\
\text { mechanism }^{5}\end{array}$ & SAPRC-996 & CB-IV7 & SARPC-99 & SAPRC-99 & RADM $^{8}$ & RADM2 & SAPRC-99 \\
\hline
\end{tabular}

Global

\begin{tabular}{|c|c|c|c|c|c|}
\hline & Harvard Ig & Harvard $2^{\text {h }}$ & $\mathrm{CMU}^{\mathrm{i}}$ & Illinois $\mathrm{I}^{\mathrm{i}}$ & Illinois $2^{j}$ \\
\hline Simulation period & 5 summers/falls & 5 summers & 10 summers/falls & 5 summers & 5 summers \\
\hline GCM & GISS III & GISS II' & GISS II' & PCM & PCM \\
\hline Grid & $4^{\circ} \times 5^{\circ}$ & $4^{\circ} \times 5^{\circ}$ & $4^{\circ} \times 5^{\circ}$ & $2.8^{\circ} \times 2.8^{\circ}$ & $2.8^{\circ} \times 2.8^{\circ}$ \\
\hline GHG scenario & Alb & Alb & $\mathrm{A} 2$ & AlFi & $\mathrm{BI}$ \\
\hline GCTM & GEOS-Chem & GISS II'9 & GISS II' & MOZART, version 4 & MOZART, version 4 \\
\hline
\end{tabular}


the Gulf Coast, which is in agreement with NERL), with weaker increases in the upper Midwest. In addition, these changes tend to be larger than those from the NERL experiment. The WSU experiment shows the largest increases in the Northeast, parts of the Midwest, and desert Southwest, with decreases in the West, the Southeast, the plains states, and the Gulf Coast. ${ }^{3}$ As is to be expected, the NERL and GNM patterns are quite similar, with differences reflecting the averaging over five compared to three summers, respectively (this highlights the potential importance of interannual variability in driving differences between modeling groups). The earlier Columbia study (for the eastern half of the United States only) shows the largest $\mathrm{O}_{3}$ increase over the lower Midwest and the mid-Atlantic regions.

Certain regions show greater agreement across experiments than others, at least in a very general sense.
For example, Fig. 1 shows that a loosely bounded area, encompassing parts of the mid-Atlantic, Northeast, and lower Midwest regions, tends to show at least some $\mathrm{O}_{3}$ increase across all the simulations. By contrast, the West and the Southeast/Gulf Coast are areas of greater disagreement. Even for these regions, however, at least some of the models (including the global models discussed in the following subsection) show substantial climate-induced $\mathrm{O}_{3}$ increases.

Several important meteorological- and meteorology-related parameters drive these changes in $\mathrm{O}_{3}$ concentration. These mean future-minus-present changes are shown in Figs. 3-5. Changes in mean $\mathrm{O}_{3}$ will tend to result, however, from meteorological changes on the daily to multiday time scales of $\mathrm{O}_{3}$ episodes (refer to sidebar), so the longer-term averages shown in these figures will necessarily only tell part of the story.

\footnotetext{
${ }^{3}$ Note that the WSU results are for July only as opposed to averages over June, July, and August as for all the other simulations. This may have some consequences for direct comparison, which will be discussed further later in the paper.
}

\section{TABle 3. Continued.}

${ }^{a}$ For more details, see Steiner et al. (2006).

b For more details, see Hogrefe et al. (2004a,b); the GISS AO model refers to the model of Russell et al. (1995).

'For more details, see Leung and Gustafson (2005); Nolte et al. (2008).

${ }^{d}$ For more details, see Tagaris et al. (2007); Liao et al. (2007); Woo et al. (2008).

e For more details, see Liang et al. (2006); Huang et al. (2007, 2008); Tao et al. (2007).

${ }^{f}$ For more details, see Chen et al. (2008); Avise et al. (2009).

g For more details, see Wu et al. (2007, 2008a,b).

${ }^{\mathrm{h}}$ For more details, see Mickley et al. (2004).

'For more details, see Racherla and Adams (2006, 2008).

For more details, see Tao et al. (2007); Lin et al. (2008); Huang et al. (2008).

' Most of the models use the IPCC SRES scenarios (Nakicenovic et al. 2000) as their global GHG trajectories into the future. These scenarios represent different storylines: for example, AIb and AIFi both have rapid economic growth and a mid-century peak in population but with energy technology in Alb spread among a diversity of sources, whereas fossil fuels dominate in AIFi; $\mathrm{BI}$ has a population profile similar to Alb and AIFi but with a rapid transition to clean energy and efficient use of resources; and $\mathrm{A} 2$ has a continuously increasing population and a highly regional world economy.

${ }^{2}$ CMM5 is based on the standard MM5 but with modifications to the buffer zone, ocean interface, and cloud-radiation interactions.

${ }^{3}$ For more details, see Byun and Schere (2006).

${ }^{4} \mathrm{AQM}$ has been adapted from the SAQM, incorporating a faster, more accurate numerical solver for gas-phase chemistry.

${ }^{5}$ Notice that the SAPRC-99 and RADM2 chemical mechanisms recycle isoprene nitrate, whereas the CB-IV mechanism does not.

${ }^{6}$ For more details, see Carter (2000).

${ }^{7}$ For more details, see Gery et al. (1989).

${ }^{8}$ For more details, see Stockwell et al. (1990).

9 The GISS II' model was coupled to the Harvard tropospheric $\mathrm{O}_{3}-\mathrm{NO}_{x}$-hydrocarbon chemical model; for more details, see Mickley et al. (1999). 
One way to summarize what Figs. $3-5$, in conjunction with Fig. 1, are showing us is that $\mathrm{O}_{3}$ largely responds to the meteorological drivers in a qualitatively consistent manner across the different climate change experiments, but the regional patterns of relative changes in these drivers are highly variable across these sets of simulations. In other words, there are important differences in the simulated future regional climate changes that seem to drive the differences in the regional patterns of $\mathrm{O}_{3}$ increases and decreases as a result of differences in the modeling systems, model configuration, and experimental design choices used by the different groups.

(a) NERL

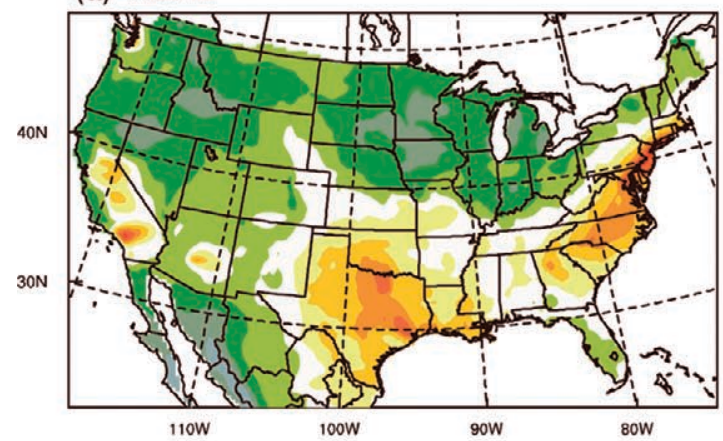

(c) Illinois 1
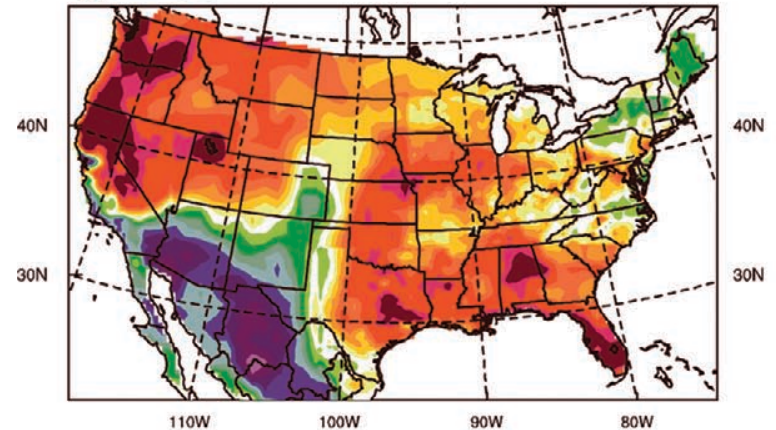

(e) WSU
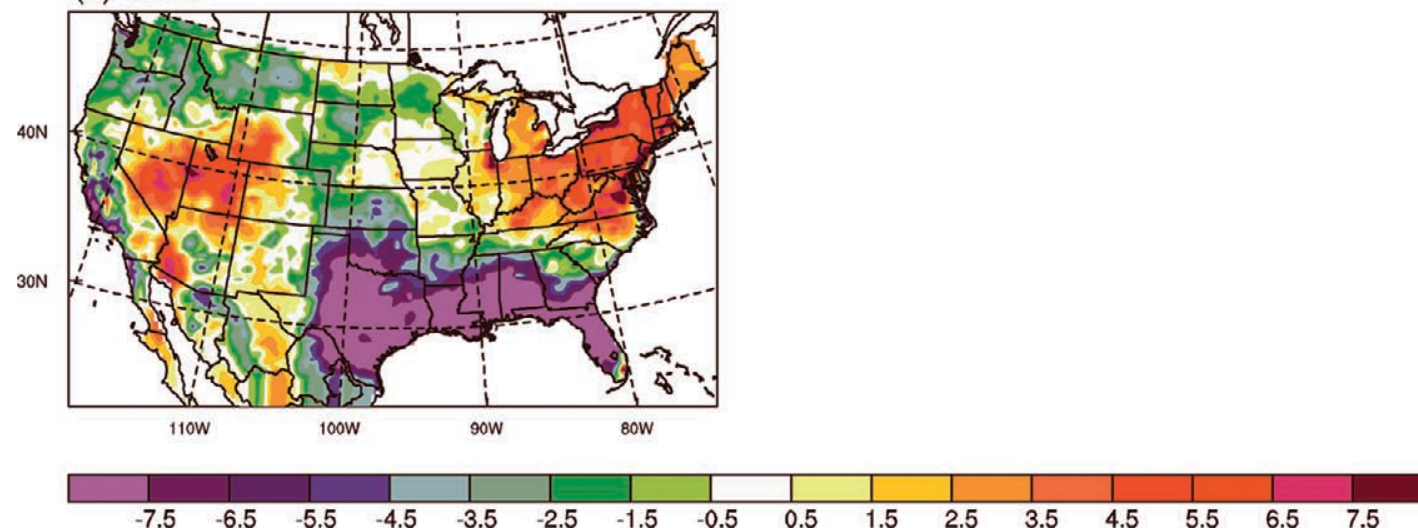

FIG. I. Future (2050s)-minus-present differences in simulated summertime-mean MDA8 $\mathrm{O}_{3}$ concentrations (ppb) for the (a) NERL, (b) Illinois I, (c) Illinois 2, (d) WSU, and (e) GNM experiments (see Table 3).

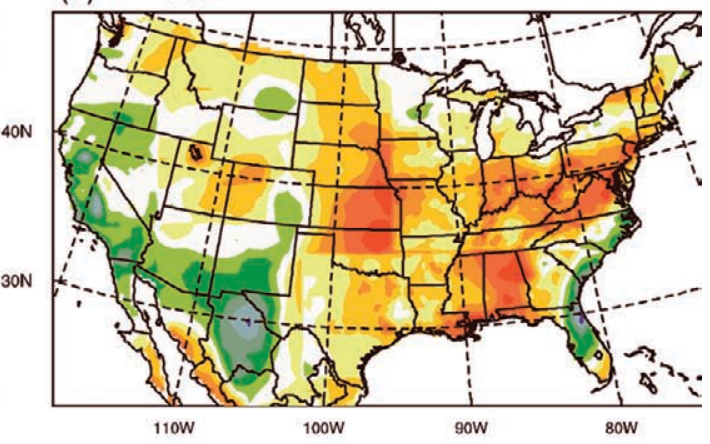

Specifically, Figs. 3 and 4 display the average future-minus-present differences in near-surface air temperature and surface insolation, which are two of the most critical meteorological drivers of ground-level $\mathrm{O}_{3}$. The insolation changes largely reflect changes in cloud cover. Other variables examined include average daily maximum temperature, precipitation, number of rainy days, and boundary layer depth. However, none of these additional comparisons is shown here, as they largely mirror the relationships with temperature and surface insolation because of the strong correlations among a number of these variables.

(b) GNM

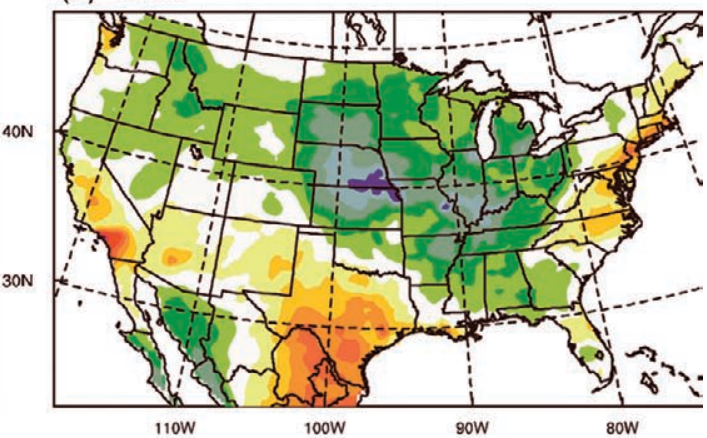

(d) Illinois 2 
Combined with the $\mathrm{O}_{3}$ results shown in Figs. 1, Figs. 3-4 reveal some key similarities of the relationships between $\mathrm{O}_{3}$ and meteorological drivers among the different model studies. First, in many regions the $\mathrm{O}_{3}$ concentration changes seem to correspond relatively well with combined changes in mean temperature (Fig. 3) and mean surface insolation (Fig. 4). For example, the NERL results show the $\mathrm{O}_{3}$ increases corresponding with temperature and insolation increases in the mid-Atlantic and Gulf Coast regions and

FIG. 2. Differences of the 95th percentile MDA8 $\mathrm{O}_{3}$ concentration for the NERL experiment.

(a) NERL

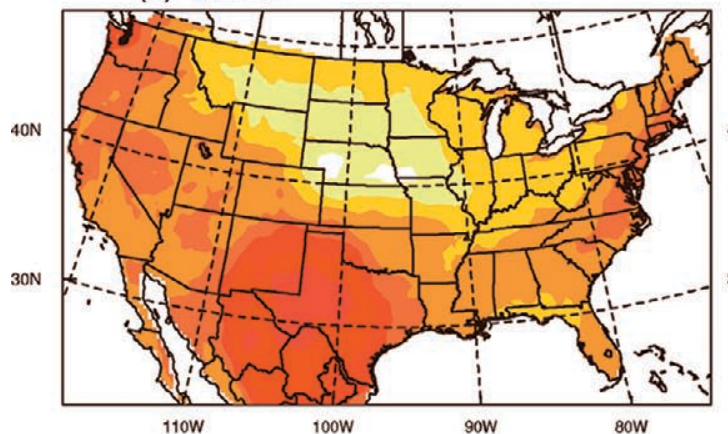

(c) Illinois 1

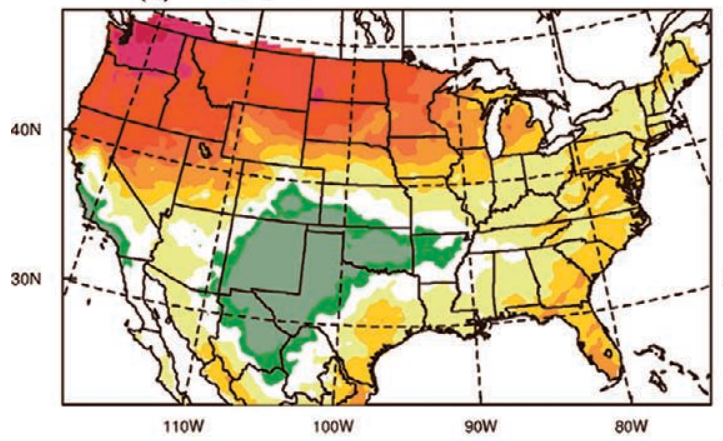

(e) WSU

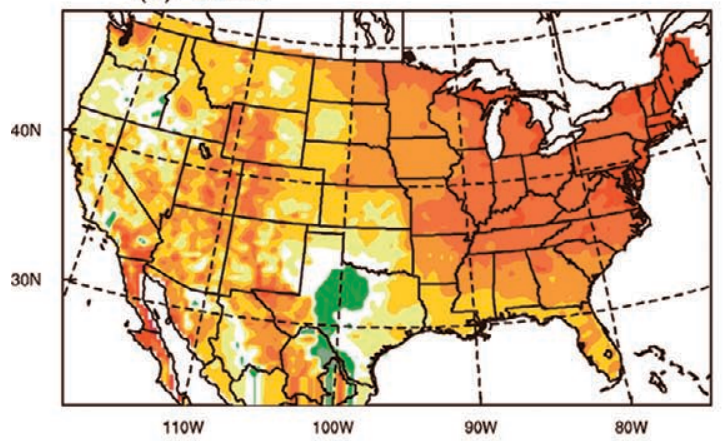

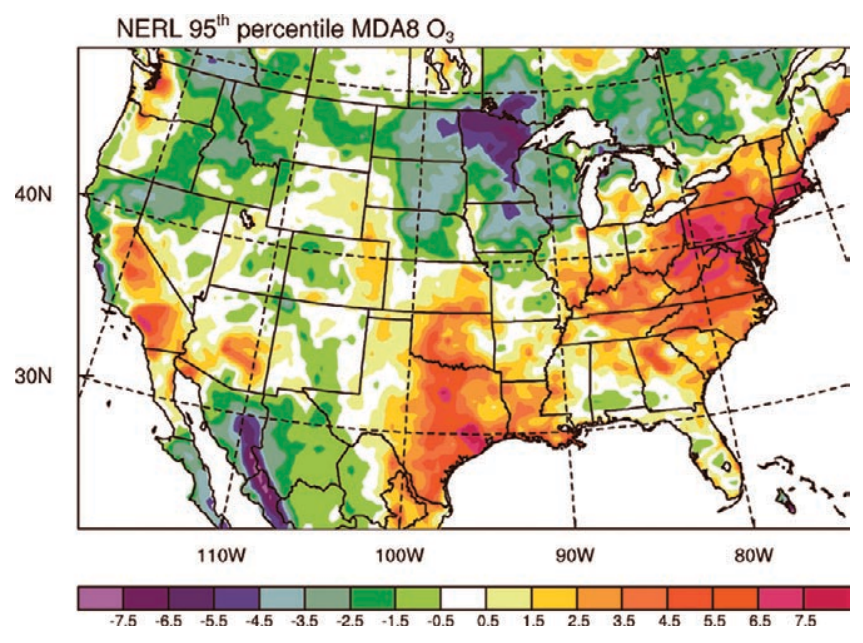

(b) GNM

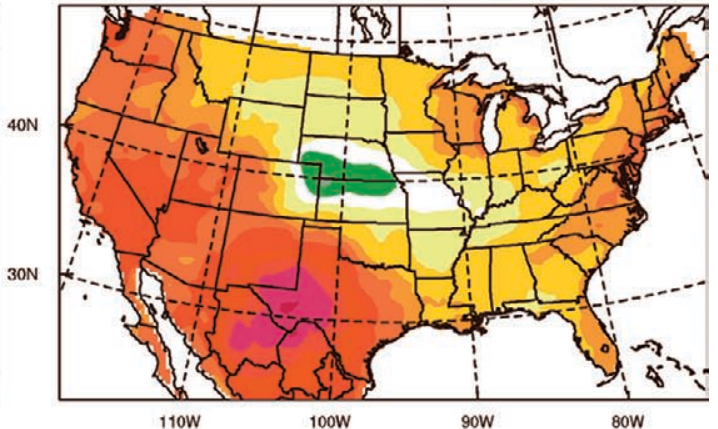

(d) Illinois 2

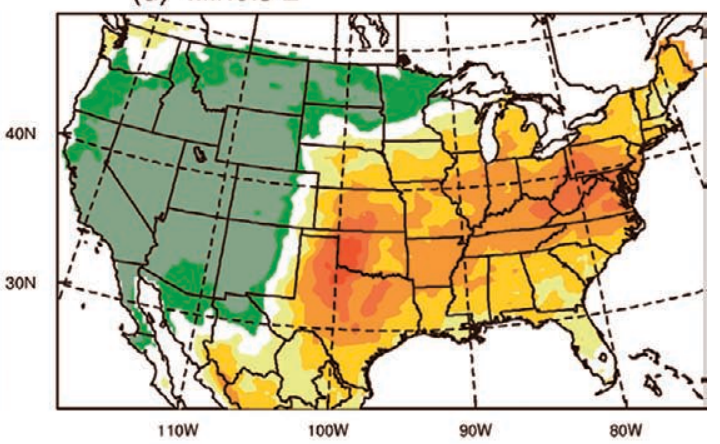

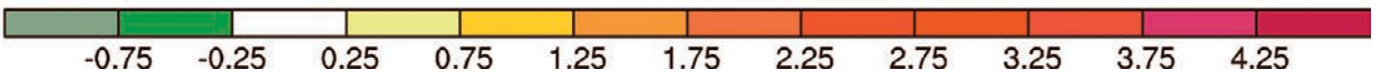

FIG. 3. Same as Fig. I but for near-surface air $\mathrm{T}\left({ }^{\circ} \mathrm{C}\right)$. 
$\mathrm{O}_{3}$ decreases associated with the insolation decreases and the local minimum in temperature increases in the upper Midwest and the northern plains. In other regions, temperature and insolation vary in opposite directions, with mixed effects on $\mathrm{O}_{3}$ concentrations. For example, in the Illinois-1 simulations, despite insolation decreases over much of the Northwest, the large increase in temperature there seems to drive $\mathrm{O}_{3}$ increases. Finally, in a small number of regions across the simulations, there is no strong correspondence between $\mathrm{O}_{3}$ concentrations and either insolation or temperature (e.g., the areas around Oklahoma in the Illinois-1 experiment and Nevada/Utah/Idaho in the

(a) NERL

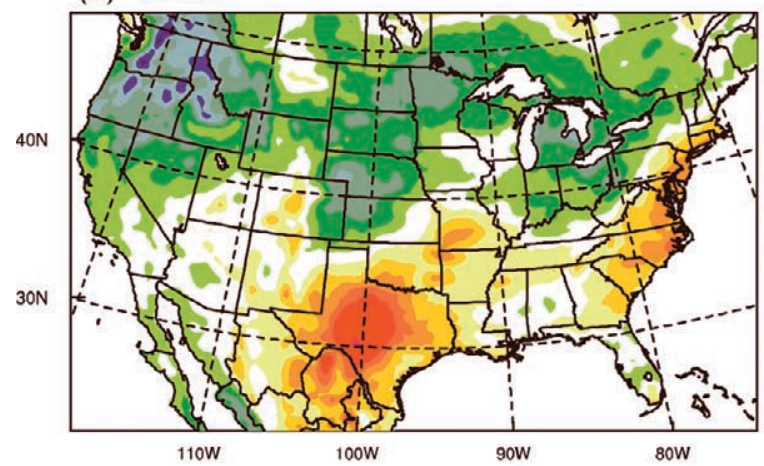

(c) Illinois 1

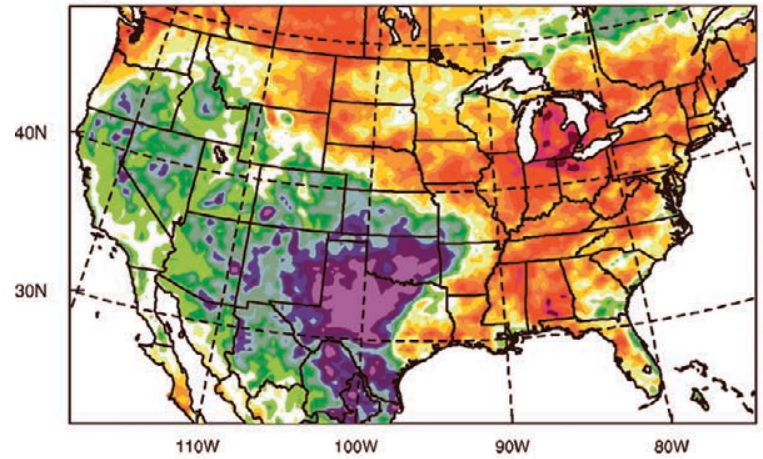

(e) WSU

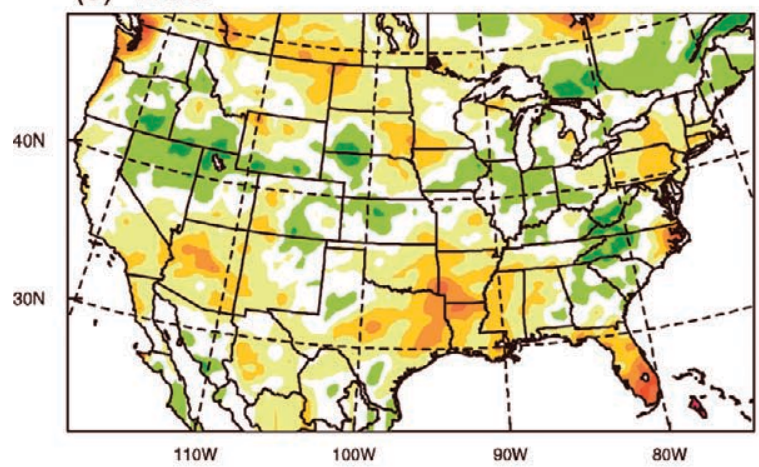

Illinois-2 experiment), suggesting that other forcing factors may be important and/or that a correspondence might exist, but only for different averaging periods and statistics of these variables. The differences between the NERL and GNM results from Figs. 1, 3, and 4 are consistent with these insights-for example, in the Plains states, GNM shows greater $\mathrm{O}_{3}$ decreases, consistent with the differences in temperature and insolation trends between the results from the two groups.

Figure 5 shows the patterns of changes in mean biogenic VOC emissions. As documented in earlier work (e.g., Chameides et al. 1988; Roselle et al. 1991;

(b) GNM

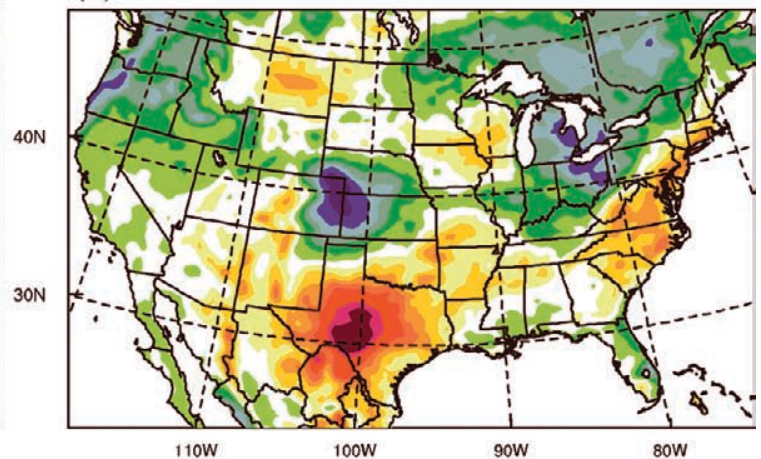

(d) Illinois 2

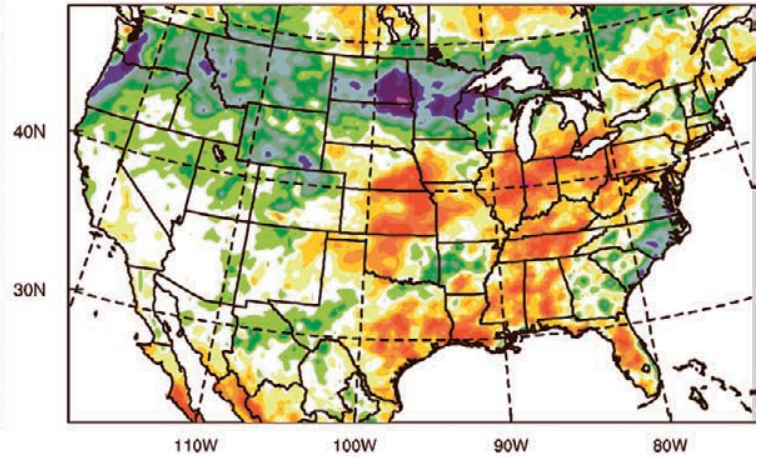

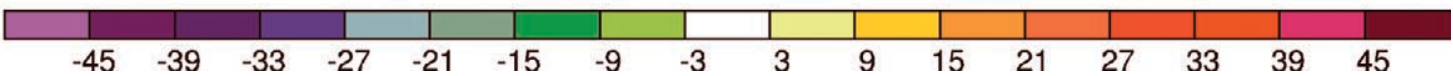

FIG. 4. As in Fig. I, but for surface insolation $\left(\mathrm{W} \mathrm{m}^{-2}\right)$. 
Guenther et al. 1994; Pierce et al. 1998; Fuentes et al. 2000; Purves et al. 2004; among others), the emissions of these important natural $\mathrm{O}_{3}$ precursors are themselves sensitive to meteorology, including sunlight and temperature. Therefore, in conjunction with the direct forcing exerted on $\mathrm{O}_{3}$ processes by changes in meteorology, climate-induced changes in biogenic emissions levels can lead to changes in $\mathrm{O}_{3}$ concentrations as well (see also Zhang et al. 2008). As will be discussed again later, in the context of the global modeling results, this effect depends on the relative amounts of $\mathrm{NO}_{\mathrm{x}}$ and VOCs in the environment. For example, the Berkeley experiment found significant
$\mathrm{O}_{3}$ concentration increases in the high- $\mathrm{NO}_{x}$ San Francisco Bay area due to increases in biogenic VOC emissions, whereas even larger increases in biogenic emissions over the Sierras actually produced slight $\mathrm{O}_{3}$ decreases.

The climate-induced biogenic emissions changes (Fig. 5) seem to contribute to the $\mathrm{O}_{3}$ concentration changes, but only in some regions and not wholly consistently across model studies. For example, temperature-driven increases in biogenic emissions may contribute to the earlier-mentioned $\mathrm{O}_{3}$ increases in the Northwest in the Illinois-1 experiment, the mid-Atlantic region in the NERL and GNM experi- (a) NERL

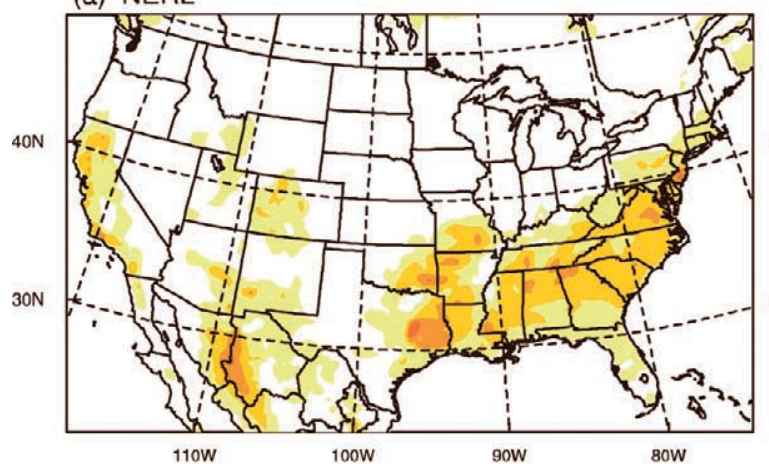

(c) Illinois 1

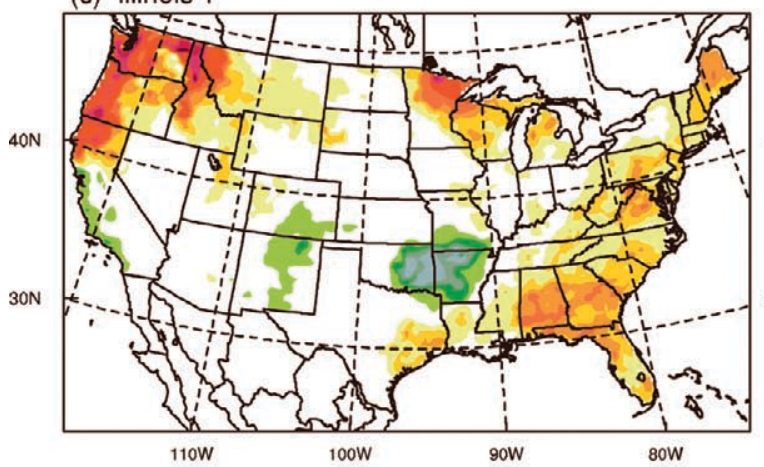

(e) WSU

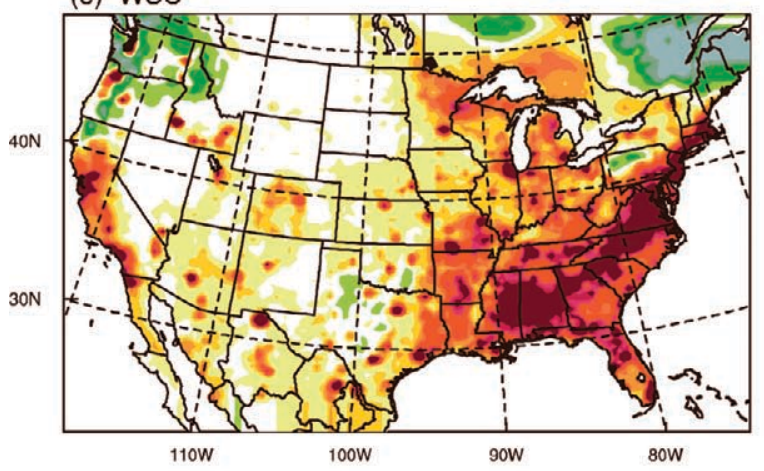

(b) GNM

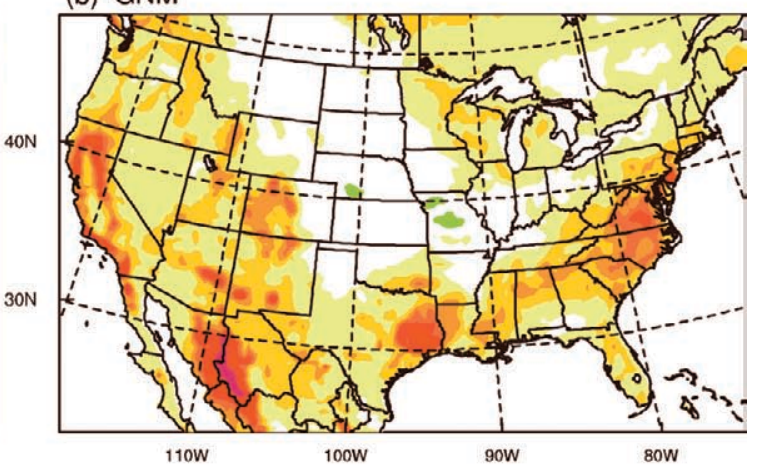

(d) Illinois 2

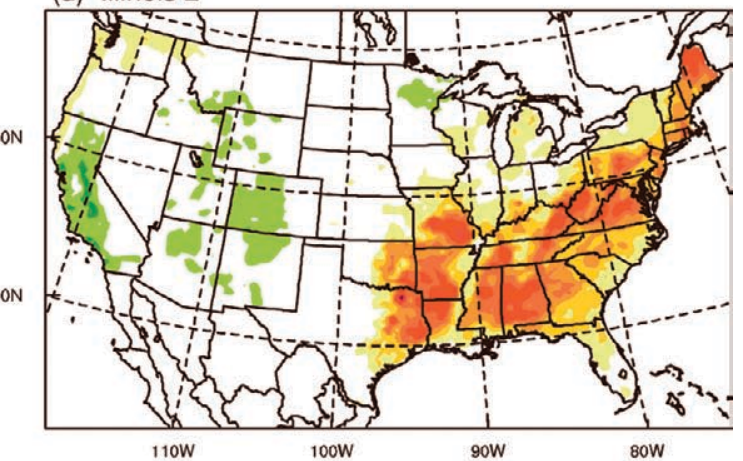

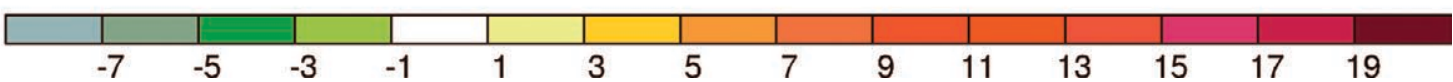

FIG. 5. As in Fig. I, but for biogenic VOC emissions (in $\mathrm{g} \mathrm{C}^{-2} \mathrm{day}^{-1}$ ). 


\section{AQM subregion}

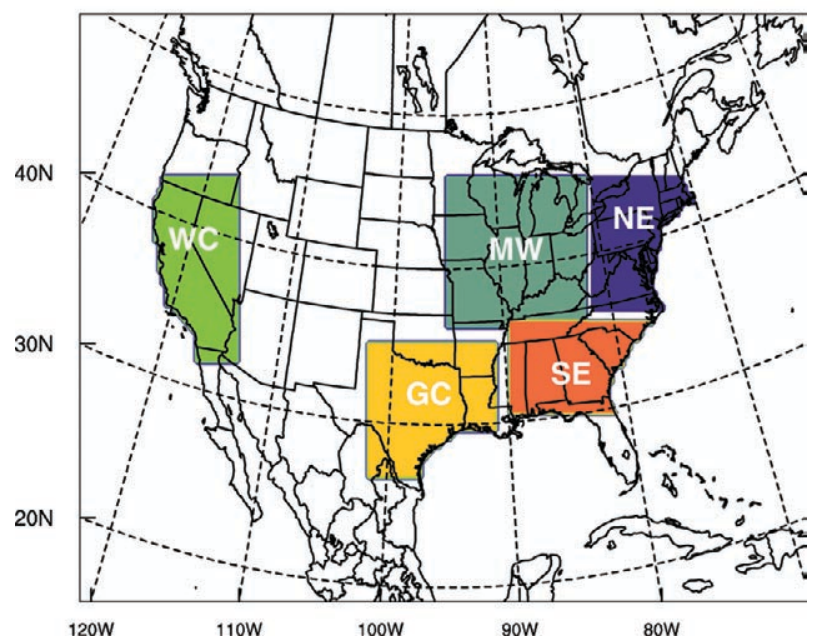

FIG. 6. The averaging subregions used in Fig. 7.

ments, the Northeast in the Illinois-2 experiment, and the Southeast in the Illinois-1 experiment. In contrast, in parts of the Southeast and the mountainous West in the NERL and GNM experiments, emissions increase significantly but $\mathrm{O}_{3}$ concentrations do not change. Notably, the WSU simulation shows large decreases in $\mathrm{O}_{3}$ in some of the parts of the Southeast and Gulf Coast where increases in VOC emissions are the strongest, a result that is partially attributed to increases in precipitation. Where there are strong correlations between biogenic emissions changes and $\mathrm{O}_{3}$ concentration changes, often there are similarly strong changes in insolation and/ or temperature, so separating the different effects is not always straightforward. The earlier work by the Columbia group found the strongest increases in emissions in the Southeast, similar to the results from the NERL and Illinois 1- and -2 experiments, but found that the largest $\mathrm{O}_{3}$ concentration changes that could be attributed to biogenic emissions changes occurred instead in parts of the Ohio Valley and the coastal midAtlantic region.

Discerning the precise chemical pathways whereby $\mathrm{O}_{3}$ responds to changes in biogenic emissions, and how these pathways vary as a function of region and climatic conditions, is an area of ongoing scientific inquiry. Different air quality models employ different representations of these pathways in their code. As such, differences between the simulated $\mathrm{O}_{3}$ response to changes in simulated biogenic emissions from different modeling systems is at this time a key source of uncertainty in climate change effects on future air quality, particularly in regions where the effect of increasing VOC concentrations is highly dependent on $\mathrm{NO}_{x}$ levels. It will be discussed further in the intercomparison of the results from the two GCTM experiments whether or not the air quality model recycling isoprene nitrate appears to be a key determinant of the response of $\mathrm{O}_{3}$ to climate-induced changes in biogenic VOC emissions. Table 3 shows that all the regional model experiments whose results are shown in Fig. 1 have chemical mechanisms that do recycle isoprene nitrate.

Figure 6 shows the averaging subregions used in Fig. 7, which summarizes these results by showing regional averages from all the modeling groups of the climate-induced differences in ozone and the drivers we have discussed earlier. (For future reference, Fig. 7 also shows the averages for the two global modeling experiments discussed below.)
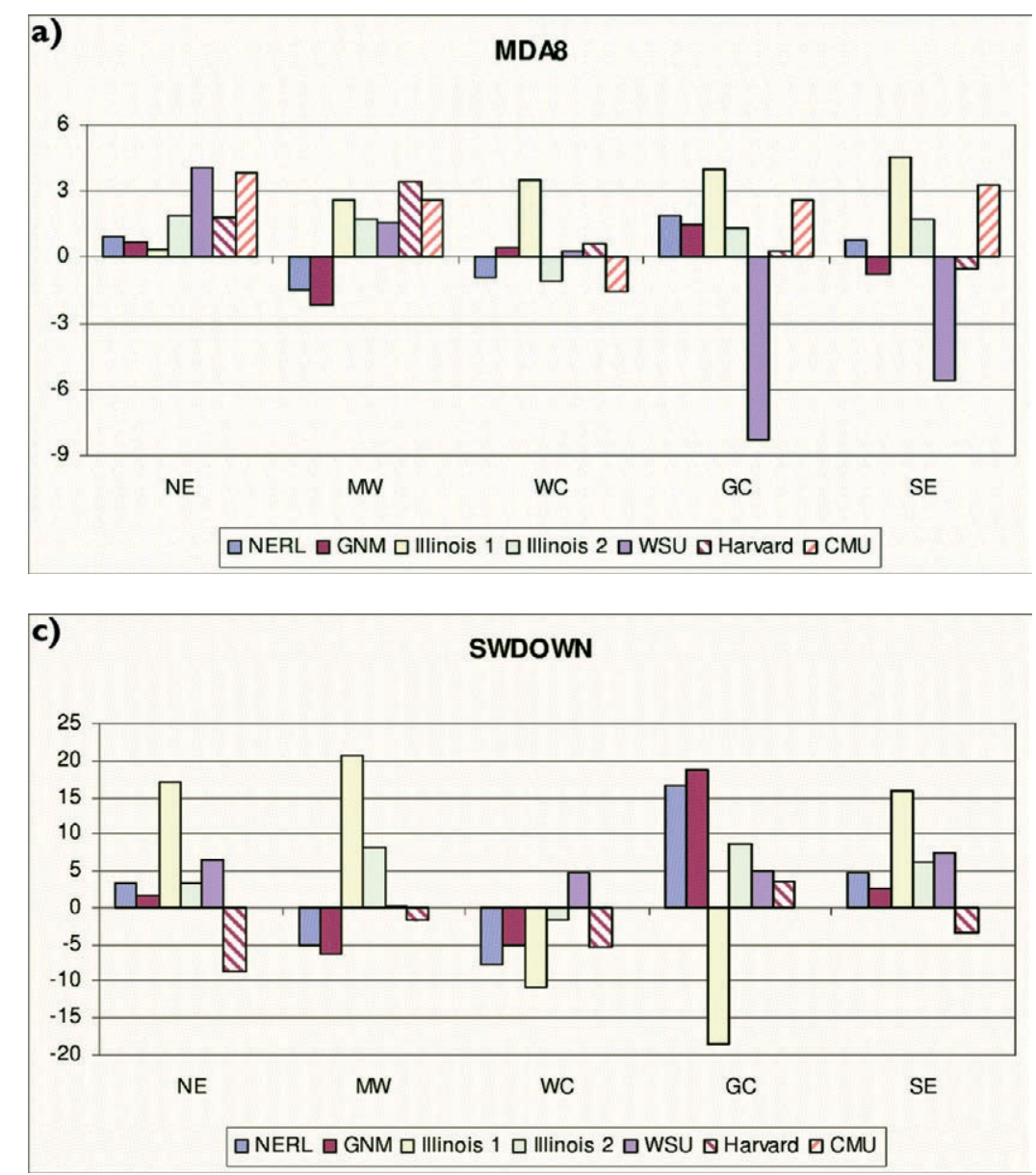
The regional modeling findings presented here are generally consistent with the relatively few regional climate change and air quality modeling experiments recently carried out for Europe. For example, Forkel and Knoche (2006) simulated changes in near-surface $\mathrm{O}_{3}$ concentrations between the 1990s and the 2030s over southern Germany under climate change but no change in anthropogenic emissions. They found a $10 \%$ increase in average daily maximum $\mathrm{O}_{3}$ during summer (approximately 2-6 ppb, depending on location in the model domain). Langner et al. (2005), in a set of regional modeling experiments, found climate change-induced increases in April-September $\mathrm{O}_{3}$ concentrations during the mid-twentieth century compared to the present over southern and central Europe, with decreases over northern Europe, and that these changes were significant with respect to interannual variability. Meleux et al. (2007) found higher summertime $\mathrm{O}_{3}$ concentrations under future climate conditions over Europe, primarily due to increased temperatures, decreased cloudiness and precipitation, and increases in biogenic VOC emissions. They also found large regional variability in these $\mathrm{O}_{3}$ changes. Finally, Szopa and Hauglustaine
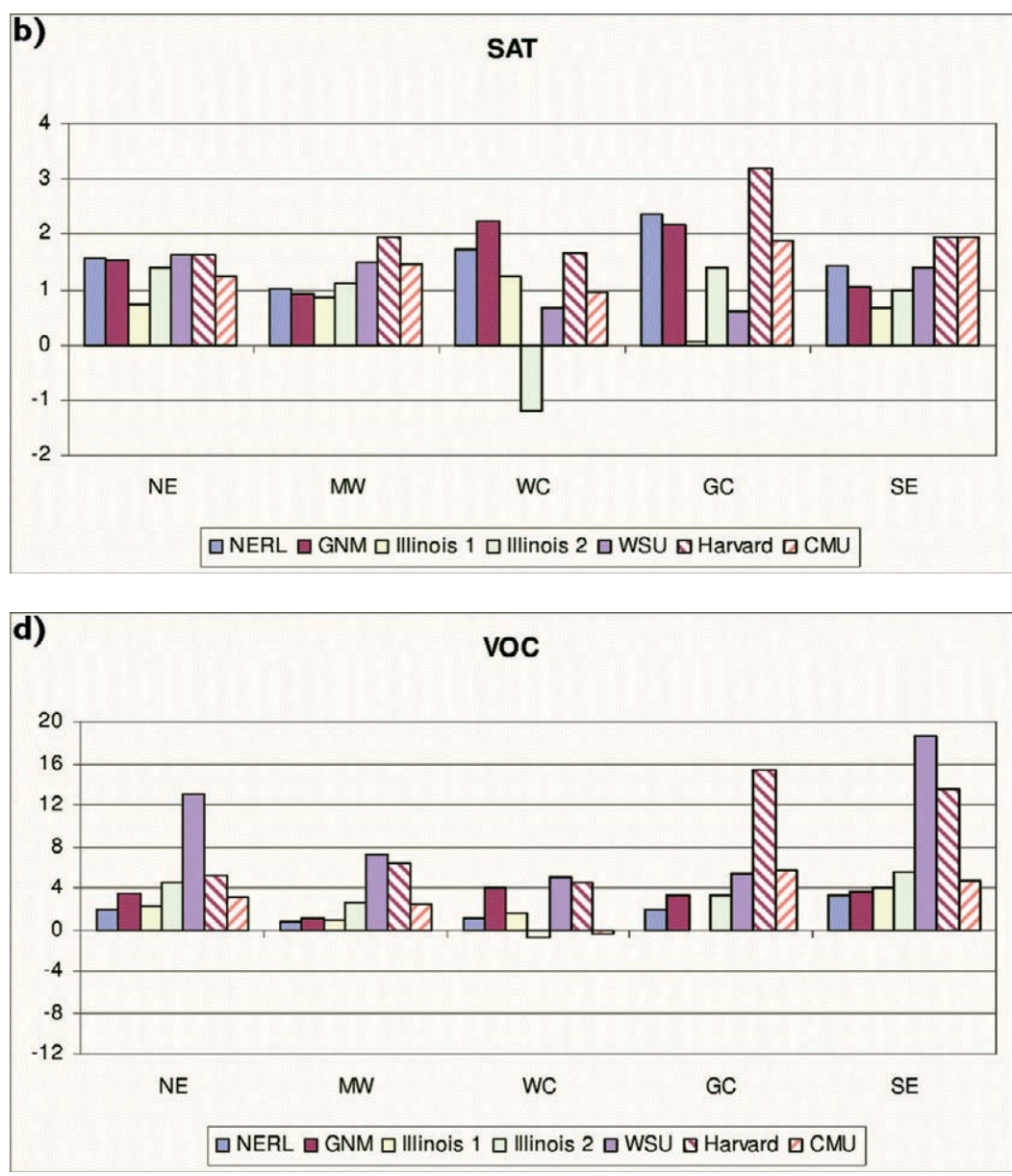

(2007) found worsening $\mathrm{O}_{3}$ conditions over Europe as a result of anticipated climate change in 2030, though this was sensitive to the choice of global and regional emissions change scenarios.

Global modeling results. A comparison of results (not shown) from all the global experiments listed in Table 3 supports the most general conclusions from the regional modeling studies; that is, large regions of the country show future $\mathrm{O}_{3}$ concentration increases of a few to several parts per billion, and there are significant differences in the spatial patterns of these changes between the simulations. In a global context, the results from these simulations are generally consistent with other GCTM climate change experiments (e.g., see Murazaki and Hess 2006; Stevenson et al. 2006; Zeng et al. 2008)—for example, decreases in background $\mathrm{O}_{3}$ concentrations in clean environments (e.g., the oceans) because of increased water vapor concentrations and increases regionally over the polluted continents.

A more detailed look at these simulations helps illustrate two additional points: (i) the potential importance for simulated future $\mathrm{O}_{3}$ of large-scale circulation changes and (ii) the importance of how isoprene chemistry is represented in the modeling systems.

Figure 8 shows the mean MDA $8 \mathrm{O}_{3}$ changes from the Harvard-1 experiment, along with accompanying changes in temperature, insolation, and biogenic emissions. In these results, the largest $\mathrm{O}_{3}$ increases are mostly in a sweeping pattern from the central United States, across the plains states and the Midwest, and extending into the Northeast. In contrast to the regional model results shown earlier, there is not as obvious a spatial correlation between the changes in $\mathrm{O}_{3}$ and those of any one of the driver

Fig. 7. Averages across the subregions shown in Fig. 6 for each of the simulations for mean summer future-minus-present differences in (a) $\mathrm{MDA}_{8} \mathrm{O}_{3}$ (ppb); (b) near-surface air temperature $\left({ }^{\circ} \mathrm{C}\right)$; (c) surface insolation $\left(\mathrm{W} \mathrm{m}^{-2}\right)$; and (d) biogenic VOC emissions $\left(\mathrm{g} \mathrm{C} \mathrm{m}^{-2}\right.$ day $\left.^{-1}\right)$. 
variables. The insolation increase in the Midwest matches, to some degree, the pattern of $\mathrm{O}_{3}$ increase there; however, the largest temperature, insolation, and biogenic emissions increases occur in the southern part of the country, where there are much smaller changes in $\mathrm{O}_{3}$. This weak relationship also holds for a number of other variables considered but not shown (e.g., precipitation, PBL height, and so on).

In Fig. 9, which shows the same quantities for the CMU experiment, a different regional pattern of change emerges. In the CMU experiment, the major increase in future $\mathrm{O}_{3}$ concentration is instead centered on the Gulf Coast and eastern seaboard, with minimal $\mathrm{O}_{3}$ changes in the upper Midwest and northern plains states.

The differences between these two sets of results can seemingly mostly be explained by two factors: (i) differences in the future simulation of the summertime storm track across the northern part of the country and (ii) differences in the modeled chemical mechanism for isoprene oxidation in the southeastern United States.

(a) $\mathrm{MDA} 8 \mathrm{O}_{3}$

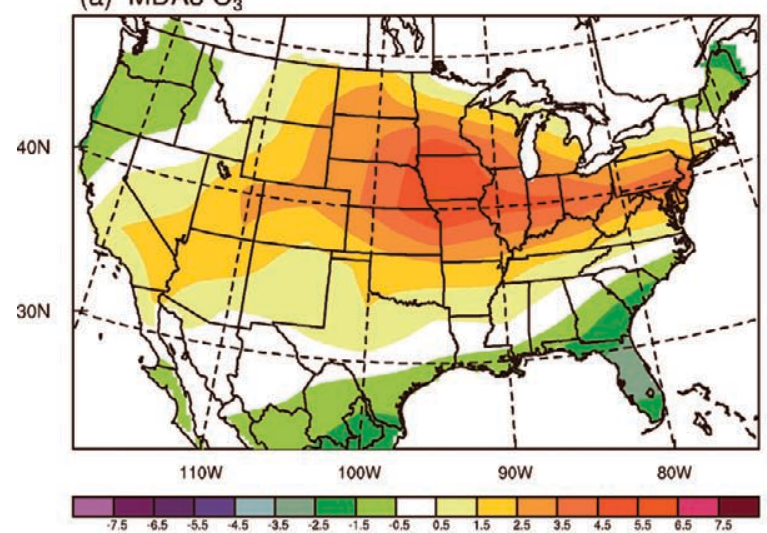

(c) Short Wave

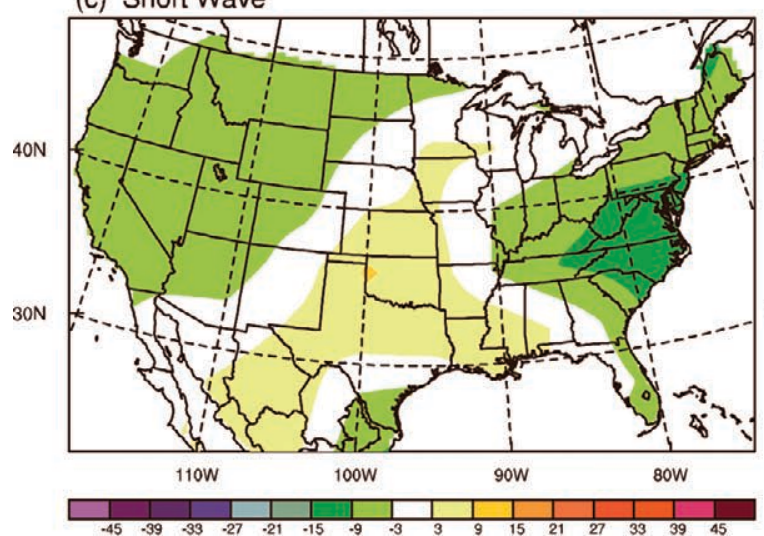

As explained in $\mathrm{Wu}$ et al. (2008a), there are two distinct dynamical shifts from the present to the future climate in the Harvard-1 experiment: a decrease in summertime cyclones tracking across the upper part of the United States, resulting in a decrease in cloudiness and precipitation over the upper Midwest (as reflected in the insolation changes shown in Fig. 8), and a northward shift of the Bermuda high, resulting in a decrease in convective activity over the Gulf Coast and the southern Great Plains. All other factors being equal, both shifts might be expected to contribute to $\mathrm{O}_{3}$ concentration increases in their respective regions.

In this context, the spatial pattern of $\mathrm{O}_{3}$ concentration increases in Fig. 8a is certainly consistent with the decrease in cyclones in the north in the Harvard-1 experiment, as suggested in $\mathrm{Wu}$ et al. (2008a) and originally posited in Mickley et al. (2004); that is, the decrease in cold surges in the simulated future climate leads to a decrease in the clearing of pollutants from the boundary layer. Racherla and Adams (2008), on the other hand, examined the distribution of sea level

(b) SAT

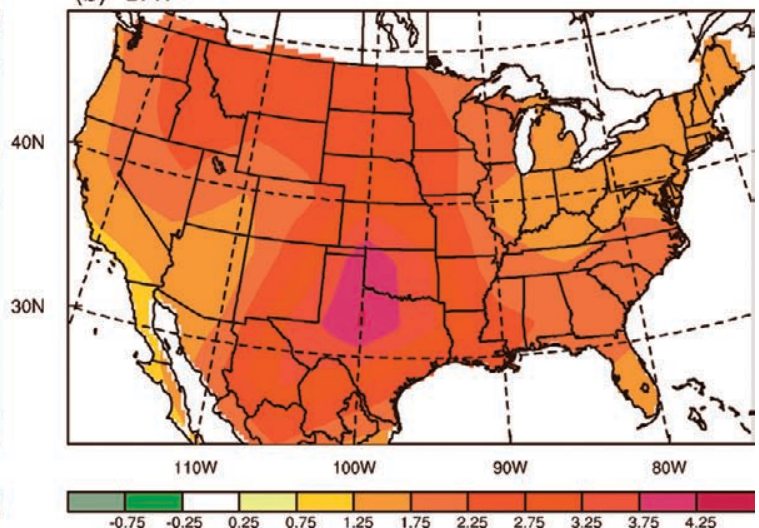

(d) Biogenic VOC

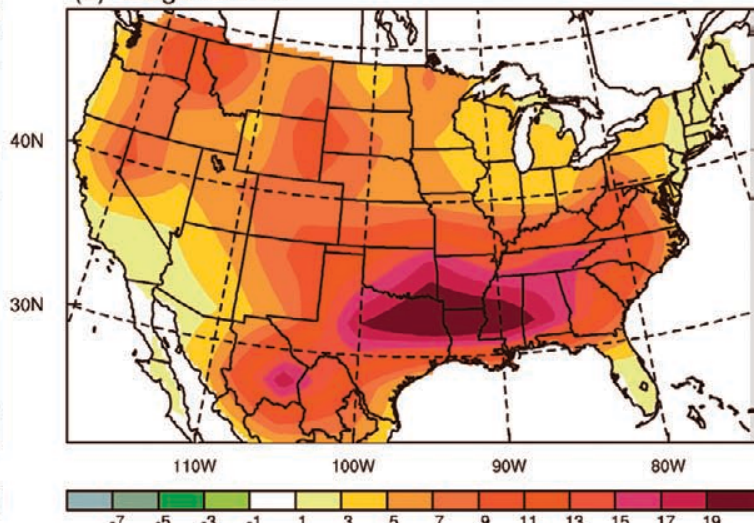

FIG. 8. Future-minus-present differences in simulated summertime mean (a) MDA8 $\mathrm{O}_{3}$ concentration (ppb); (b) near-surface air temperature ( $\left.{ }^{\circ} \mathrm{C}\right)$; (c) surface insolation $\left(\mathrm{W} \mathrm{m}^{-2}\right)$; and (d) biogenic isoprene emissions $\left(\mathrm{g} \mathrm{C} \mathrm{m}^{-2} \mathrm{sec}^{-1}\right)$ for the Harvard I global modeling experiment (see Table 3 ). 
pressure anomalies in the present-day and future CMU simulations and found only relatively small changes in these regions. These results suggest that storm-track activity does not decrease as much in this CMU model simulation [see also Leibensperger et al. (2008) for further discussion]. In any case, it seems plausible that differences in simulated future largescale circulation patterns explain the differences in future $\mathrm{O}_{3}$ changes simulated in the two experiments for the northern part of the country.

The even larger differences in simulated future $\mathrm{O}_{3}$ changes in the southern half of the country likely arise because of differences in how isoprene chemistry is described in the Harvard-1 and CMU modeling systems, leading to differences in how $\mathrm{O}_{3}$ responds to the climate-induced changes in biogenic VOC emissions. The spatial patterns of future-minus-present changes in isoprene emissions shown in Figs. $8 \mathrm{~d}$ and $9 \mathrm{~d}$ are qualitatively similar, with the largest increases centered on the Southeast and Gulf Coast regions for both groups. Examining the CMU results in Fig. 9, it appears that increases in temperature and decreases in cloud cover (and hence increases in insolation) have combined to lead to increases in both isoprene emissions and $\mathrm{O}_{3}$ concentrations in this region. An additional CMU simulation with future meteorology but scaled-back isoprene emissions has confirmed that the enhanced $\mathrm{O}_{3}$ chemical production resulting from these enhanced emissions are largely responsible for the simulated future $\mathrm{O}_{3}$ increases (Racherla and Adams 2008).

This is in contrast to the Harvard-1 results in Fig. 8, which show only weak changes in $\mathrm{O}_{3}$ concentrations over the Southeast and Gulf Coast, despite the large increase in future biogenic emissions. Even the especially large increases in temperature that accompany these biogenic emissions changes over the Gulf Coast region do not seem to increase appreciably future $\mathrm{O}_{3}$ concentrations.

One factor to which this striking difference between the two sets of results might be traced is the modeled isoprene nitrate chemistry, as mentioned earlier. Although increased emissions of biogenic VOCs are often associated with increases in $\mathrm{O}_{3}$ concentrations, these increased emissions can also lead to decreases in $\mathrm{O}_{3}$ concentrations via different pathways. For example, high concentrations of isoprene can reduce $\mathrm{O}_{3}$ amounts through direct ozonolysis, and they can also suppress $\mathrm{O}_{3}$ production in $\mathrm{NO}_{\mathrm{x}}$-limited regimes (e.g., rural areas) (a) $\mathrm{MDA} 8 \mathrm{O}_{3}$

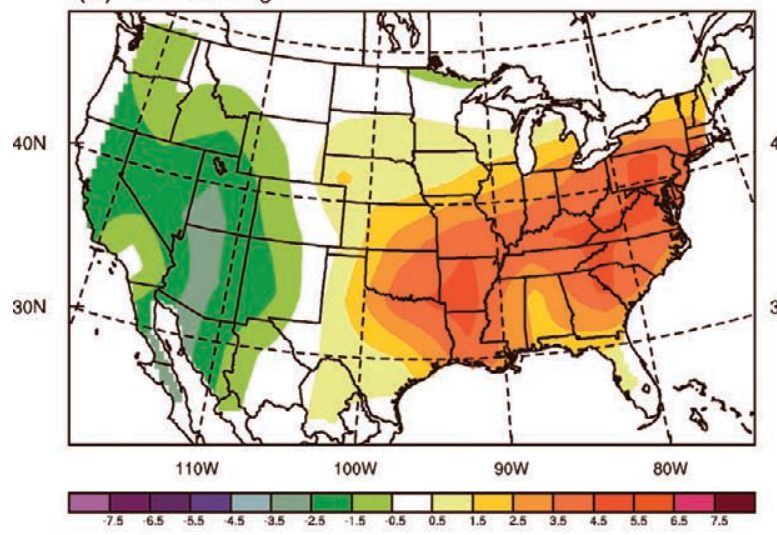

(c) Cloud

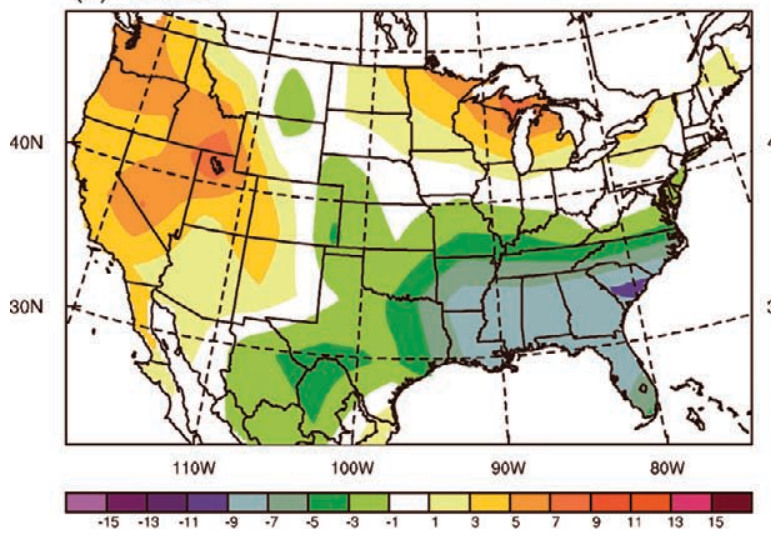

(b) SAT

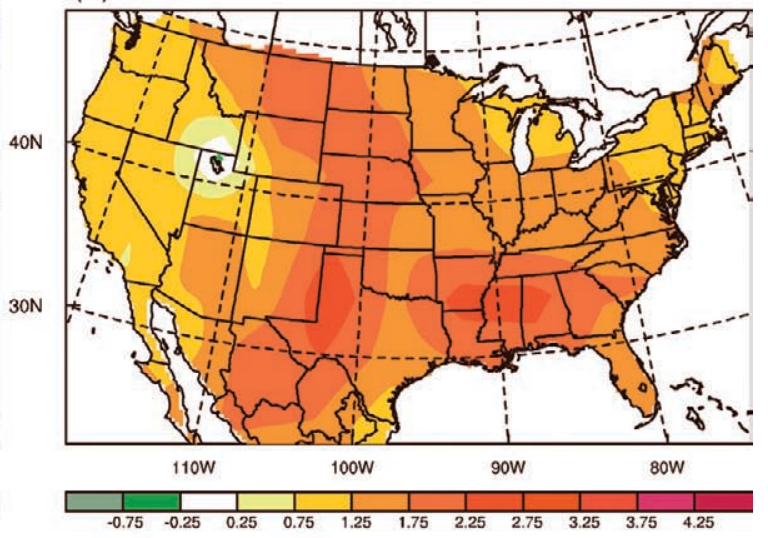

(d) Biogenic VOC

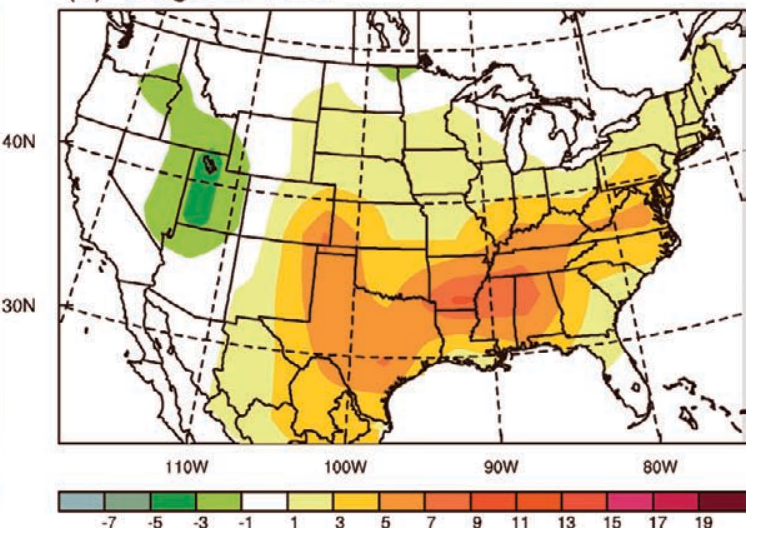

FIG. 9. As in Fig. 8 but for the CMU global modeling experiment (see Table 3). 
by sequestering $\mathrm{NO}_{\mathrm{x}}$ in isoprene nitrates (e.g., see Fiore et al. 2005). In the Harvard-1 modeling system, increasing isoprene emissions seem to result in little change, or even decreases in $\mathrm{O}_{3}$ amounts, perhaps because the model chemistry represents these isoprene nitrates as a "terminal" sink for $\mathrm{NO}_{\mathrm{x}}$. In the absence of additional $\mathrm{NO}_{x}$, the small change in $\mathrm{O}_{3}$ concentrations in the Gulf Coast, despite the strongly favorable climate changes there, could be due to this suppressing effect of isoprene. By contrast, in the CMU modeling system, the isoprene nitrates are assumed to react rapidly with $\mathrm{OH}$ and $\mathrm{O}_{3}$ and "recycle" $\mathrm{NO}_{x}$ back to the atmosphere with $100 \%$ efficiency. This $\mathrm{NO}_{\mathrm{x}}$ then becomes available to help create $\mathrm{O}_{3}$ again, tending to favor greater $\mathrm{O}_{3}$ concentrations in regions of greater biogenic VOC emissions. It is this effect that may be dominating the influence of climate change on $\mathrm{O}_{3}$ in the CMU results. This comparison strongly illustrates the importance of understanding the underlying details of the chemical mechanism of $\mathrm{O}_{3}$ formation. Constraining the precise pathways whereby isoprene, $\mathrm{NO}_{\mathrm{x}}$, and $\mathrm{O}_{3}$ are linked is the subject of ongoing research (e.g., see Horowitz et al. 2007), and as such remains an important source of uncertainty in the modeling systems.

Lastly, in the Harvard-1 simulations, enhanced ventilation and mixing also plays a role in partially offsetting expected climate-induced $\mathrm{O}_{3}$ concentration increases in some near-coastal regions. This results from the combination of the humidity-driven decreases in $\mathrm{O}_{3}$ over the oceans reported in $\mathrm{Wu}$ et al. (2008b) and Racherla and Adams (2006), and perhaps also stronger onshore flow due to an increase in the summertime land-ocean heating contrast. Lin et al. (2008) report similar effects in their simulations of future $\mathrm{O}_{3}$ over the United States and China.

SUMMARY AND DISCUSSION. This paper describes an effort to combine global and regional climate and air quality models and apply them in the study of global climate change effects on U.S. regional air quality. This effort represents a systematic attempt to use multiple modeling systems across multiple groups to investigate the regional dimensions of climate-induced air quality changes. This synthesis across a diversity of results helps determine what new scientific findings are emerging. It also allows the assessment of the current ability to simulate changes in U.S. regional air quality as a result of global climate change. The major conclusions are as follows.

First, across all of the modeling experiments carried out by the different groups, simulated global climate change causes increases in summertime $\mathrm{O}_{3}$ concentrations over substantial regions of the country. For summertime-mean MDA8 $\mathrm{O}_{3}$, the increases are in the $2-8 \mathrm{ppb}$ range. The increases in $\mathrm{O}_{3}$ concentrations in these simulations are larger during peak pollution events, as exhibited by the greater increases in 95th percentile MDA8 $\mathrm{O}_{3}$ than those for summertime-mean $\mathrm{MDA} 8 \mathrm{O}_{3}$.

Although the results from the different research groups agreed on these points, their modeling systems did not necessarily simulate the same regional patterns of climate-induced $\mathrm{O}_{3}$ changes, with the individual simulations showing regions of little changeor even decreases-in addition to the $\mathrm{O}_{3}$ increases. Drawing on all seven mean MDA8 $\mathrm{O}_{3}$ difference maps (the five regional and two global modeling sets) from Figs. 1, 8, and 9, we can see that certain regions show greater agreement than others. For example, there is very generally more agreement on the spatial patterns of climate-induced increases for the eastern half of the country than for the West, though parts of the Southeast show some of the strongest disagreements across the modeling groups. This is emphasized in another way in Fig. 10, which shows the mean and standard deviation constructed from all seven of these $\mathrm{MDA} 8 \mathrm{O}_{3}$ difference maps.

These differences in the regional patterns of $\mathrm{O}_{3}$ changes result from variations across the simulations in the patterns of mean changes in key meteorological drivers, such as temperature and surface insolation. The modeling experiments provide examples of regions where simulated future changes in meteorological variables either have reinforcing or competing effects on $\mathrm{O}_{3}$ concentrations. For example, regions where the changes in simulated temperature and insolation are in the same direction tend to experience $\mathrm{O}_{3}$ concentration changes in a similar direction, whereas temperature and insolation varying in opposite directions tend to correspond with mixed $\mathrm{O}_{3}$ changes. In short, each model experiment produces a unique pattern of key meteorological drivers, and their combined effects create the unique pattern of $\mathrm{O}_{3}$ changes seen in the individual modeling studies. It is worthwhile pointing out that the findings shown here provide yet another illustration of both the importance of the representation of clouds in climate models (here via their effect on surface insolation) and the continued challenge of doing so consistently across our current generation of models. Interannual variability plays an important role here as well, as each of the studies only simulated at most a few summers worth of climate change, thus increasing the probability that any two studies will differ from each other in their regional patterns of $\mathrm{O}_{3}$ change simply because of year-to-year differences. 
In this context, large-scale circulation patterns play an important role in modifying these local meteorological drivers. For example, how a given modeling system simulates changes in key circulation features, like the midlatitude storm track or the subtropical high pressure systems, has a strong effect on the simulated future $\mathrm{O}_{3}$ concentrations. Related factors to which the patterns in the simulated meteorological variables appear to be highly sensitive but that are not discussed in detail in this paper include the choice of convection scheme (e.g., see Tao et al. 2008) and whether or not the global model outputs are dynamically downscaled with an RCM; for example, the downscaled MM5 results for the 2050s used in the NERL experiment show increased storminess in the upper Midwest, while the GISS II' output that drove this MM5 simulation instead shows increased stagnation (Mickley et al. 2004; Leung and Gustafson 2005; Gustafson and Leung 2007). The GNM group found that the effect of overall uncertainties in climate forecasts on the simulated future fourth-highest daily MDA8 $\mathrm{O}_{3}$ to be as high as $10 \mathrm{ppb}$ in urban areas of the Northeast, Midwest, and Gulf Coast (Liao et al. 2009).

In addition, across nearly all the modeling studies, climate change is associated with simulated increases in biogenic VOC emissions over most of the United States, with the largest increases typically in the Southeast and Gulf Coast regions. The response of $\mathrm{O}_{3}$ concen-

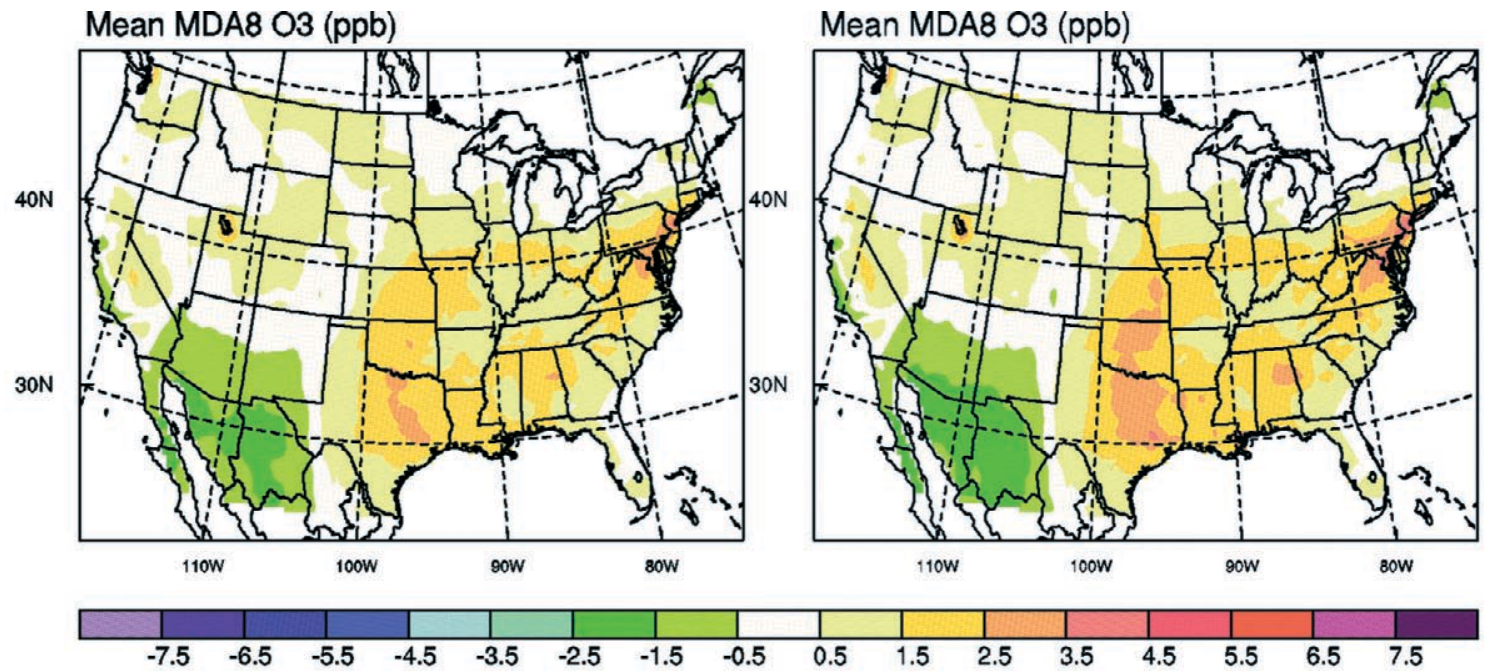

Standard Deviation in MDA8 $\mathrm{O}_{3}(\mathrm{ppb})$ Standard Deviation in $\mathrm{MDA} 8 \mathrm{O}_{3}(\mathrm{ppb})$

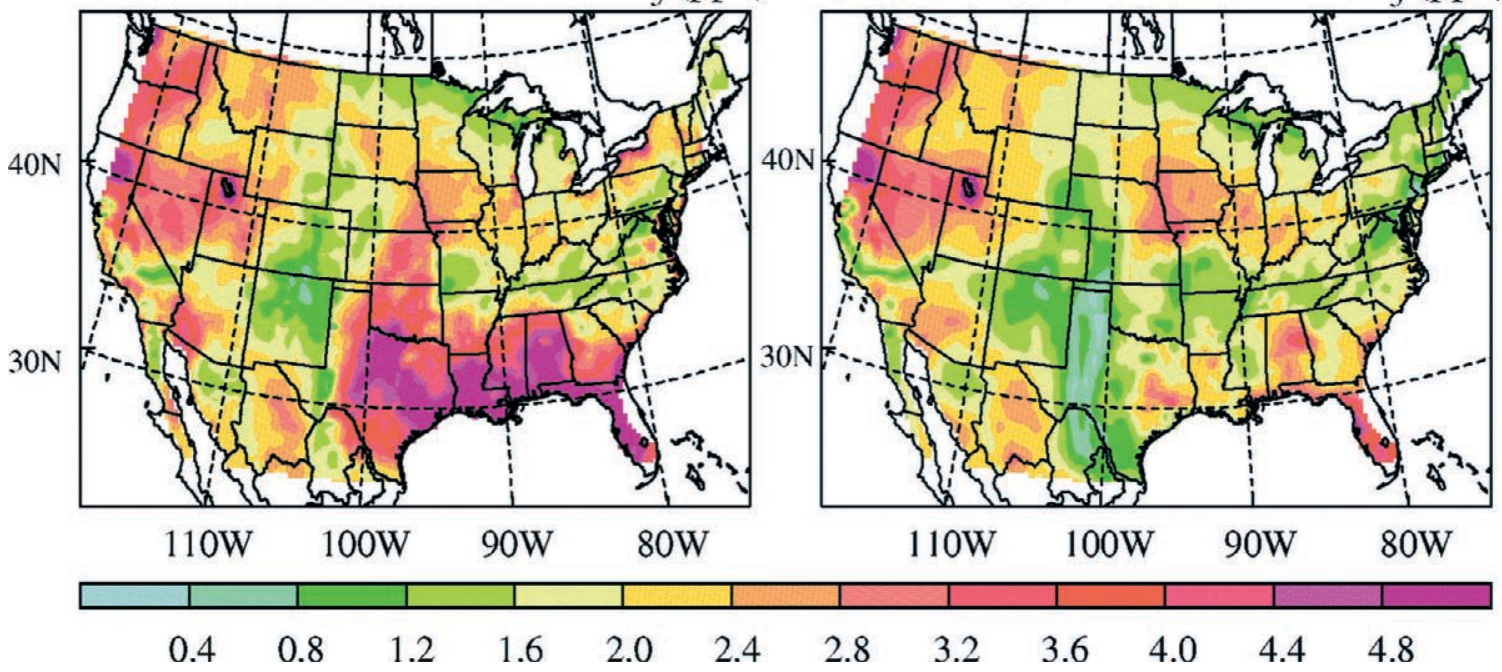

FIG. I0. The mean (top panels) and standard deviation (bottom panels) in future-minus-present MDA8 $\mathrm{O}_{3}$ concentration differences across (left-hand panels) all seven experiments (five regional and two global) shown in Figs. I, 6, and 7 and, for comparison purposes (right-hand panels), not including the WSU experiment (because it simulated differences for July only, while the other experiments simulated JJA differences). 
tration to these biogenic emissions, however, depends on both the region and the modeling system. One key factor in this variation in $\mathrm{O}_{3}$ response seems to be the representation of isoprene chemistry in the models; models that recycle isoprene nitrates back to $\mathrm{NO}_{\mathrm{x}}$ will tend to simulate significant $\mathrm{O}_{3}$ concentration increases in regions with biogenic emissions increases, whereas models that do not recycle isoprene nitrates will tend to simulate small changes or perhaps decreases.

A few of the modeling groups examined some additional issues in greater detail, augmenting the overall findings. For example, as already discussed, interannual variability in weather conditions plays an important role in determining average $\mathrm{O}_{3}$ levels and exceedances in a given year, and it likely also contributed to the differences in climate-induced $\mathrm{O}_{3}$ changes between the different groups. Nolte et al. (2008) found that in some regions of the United States, the average increase in $\mathrm{MDA} 8 \mathrm{O}_{3}$ concentrations from the present to the 2050s as a result of climate change is about as large as the present-day year-to-year variability. This means both (i) that climate change has the potential to push $\mathrm{O}_{3}$ concentrations in extreme years beyond the current envelope of natural interannual variability, and (ii) that multiyear simulations are important when trying to understand the potential for global climate change to affect regional $\mathrm{O}_{3}$ concentrations. Furthermore, although this analysis has focused on summertime results, three of the groups also found increases in $\mathrm{O}_{3}$ concentrations in some regions in the spring and fall, suggesting a possible future extension of the $\mathrm{O}_{3}$ season (Nolte et al. 2008; Chen et al. 2008; Racherla and Adams 2008).

Lastly, although this paper discusses the problem of climate change effects alone on air quality, it is of course unrealistic to assume that emissions will stay the same into the future in the face of future economic and technological development and future regulatory regimes. As described earlier in the paper, understanding the interactions and combined effects of both climate and emissions changes is the focus of the second phase of the EPA assessment effort, and a number of the modeling groups mentioned here have made some initial efforts in this direction (e.g., see Hogrefe et al. 2004b; Nolte et al. 2008; Racherla and Adams 2008; Steiner et al. 2006; Tagaris et al. 2007; Tao et al. 2007; Wu et al. 2008a,b; Zhang et al. 2008). An initial model intercomparison study of the first-order relative effects of climate and emissions changes on U.S. regional $\mathrm{O}_{3}$ concentrations has been conducted and is being prepared for a separate publication.

For the scientific research community, assessments such as the one being carried out by the EPA help convey the key knowledge gaps that limit our understanding of the problem and/or create barriers to the use and interpretation of scientific information by decision makers. In this case, coupled global climate-regional air quality science is still in a relatively youthful state. Because air quality-from a health, environmental, and regulatory perspective-is largely determined by episodes that occur during specific, sporadic weather events, the ability of available modeling tools to simulate these events and capture the variability and future changes in these episodes is important. The focus of the climate modeling community has been shifting in recent years from long-term mean values of variables such as temperature and precipitation to increased consideration of changes in variability, extremes, and the frequency of specific weather patterns. Some of this effort should be directed into more detailed considerations of the climate metrics and statistics most relevant for air quality and more evaluations of climate models for these metrics and statistics. New research carried out under the auspices of this assessment, as summarized in Leung and Gustafson (2005) and Gustafson and Leung (2007), represent advances in this direction and provide useful insights. Additionally, this assessment has helped improve the understanding of the sensitivity of simulated meteorology, and hence air quality endpoints, to model physical parameterizations (e.g., Liang et al. 2004a,b 2006; Lynn et al. 2007; Kunkel et al. 2007; Tao et al. 2008). These advances lead to a number of future research questions, including: What kinds of differences do different GCMs simulate in the climate and especially in the weather patterns that matter most for air quality? How do RCMs translate these climate and meteorological changes down to the regional scales that are desired, and what is the dependence on model physical parameterizations and downscaling methodologies? And finally, how are important chemical mechanisms represented in the climate-air quality modeling systems?

Although this is fundamentally a science assessment, and does not explicitly address policy options, this scientific information should enhance the ability of air quality managers to consider global change in their decisions. First, the development of tools and a knowledge base to answer current and future science questions about the effects of global change on air quality enables the delivery of general benefits that derive from addressing these science questions: an improved understanding of the richness and range of behaviors of the global change-air quality system and an appreciation for the strengths and limitations of the scientific tools and methods 
used to develop this improved understanding. In addition, it helps answer the "zeroth order" policy question: Is climate change something we will have to account for moving forward in air quality management? The results shown here support the conclusion that climate change should be considered in future planning.

Second, this improved system understanding, combined with a clear appreciation of the important scientific uncertainties and limitations, provides a basis for a suite of parallel, collaborative activities between the scientific research and air quality policy communities. Such activities would investigate specific air quality policy and management questions and might include the development of new tools and models explicitly for decision support (rather than scientific research), incorporating the new scientific and technical knowledge from this assessment.

ACKNOWLEDGMENTS. The authors wish to thank the three anonymous reviewers whose comments helped lead to a significantly improved paper. In addition, CPW wishes to thank members of the Global Change Assessment staff in the National Center for Environmental Assessment for its many helpful discussions and comments throughout the development of this paper. As stated in the text, much of the research synthesized here was funded through the STAR grant program of EPA's National Center for Environmental Research. The views expressed herein are those of the authors and do not necessarily reflect the views or policies of the U.S. Environmental Protection Agency, the Illinois State Water Survey, the University of Illinois at Urbana-Champaign, or any of the other institutions with which the authors are affiliated.

\section{REFERENCES}

Avise, J., J. Chen, B. Lamb, C. Wiedinmyer, A. Guenther, E. Salathé, and C. Mass, 2009: Attribution of projected changes in summertime U.S. ozone and PM2.5 concentrations to global changes. Atmos. Chem. Phys., 9, 1111-1124.

Aw, J., and M. J. Kleeman, 2003: Evaluating the firstorder effect of intraannual temperature variability on urban air pollution. J. Geophys. Res., 108, 4365, doi:10.1029/2002JD002688.

Bloomfield, P., J. A. Royle, L. J. Steinberg, and Q. Yang, 1996: Accounting for meteorological effects in measuring urban ozone levels and trends. Atmos. Environ., 30, 3067-3077.

Byun, D., and K. L. Schere, 2006: Review of the governing equations, computational algorithms, and other components of the Models-3 Community
Multiscale Air Quality (CMAQ) modeling system. Appl. Mech. Rev., 59, 51-77.

Camalier, L., W. Cox, and P. Dolwick, 2007: The effects of meteorology on ozone in urban areas and their use in assessing ozone trends. Atmos. Environ., 4, 7127-7137.

Carter, W. P. L., 2000: Implementation of the SAPRC-99 chemical mechanism into the Models-3 framework. U.S. Environmental Protection Agency Rep., $106 \mathrm{pp}$.

Chameides, W. L., R. W. Linsay, J. Richardson, and C. S. Kiang, 1988: The role of biogenic hydrocarbons in urban photochemical smog: Atlanta as a case study. Science, 241, 1473-1474.

Chen, J., and Coauthors, 2008: The effects of global changes upon regional ozone pollution in the United States. Atmos. Chem. Phys., 9, 1125-1141.

Cox, W. M., and S.-H. Chu, 1993: Meteorologically adjusted ozone trends in urban areas: A probabilistic approach. Atmos. Environ., 27B, 425-434.

Dawson, J. P., P. J. Adams, and S. N. Panis, 2007: Sensitivity of ozone to summertime climate in the eastern USA: A modeling case study. Atmos. Environ., 41, 1494-1511.

Fiore, A. M., L. W. Horowitz, D. W. Purves, H. Levy II, M. J. Evans, Y. Wang, Q. Li, and R. M. Yantosca, 2005: Evaluating the contribution of changes in isoprene emissions to surface ozone trends over the eastern United States. J. Geophys. Res., 110, D12303, doi:10.1029/2004JD005485.

Forkel, R., and R. Knoche, 2006: Regional climate change and its impact on photooxidant concentrations in southern Germany: Simulations with a coupled regional climate-chemistry model. J. Geophys. Res., 111, D12302, doi:10.1029/2005JD006748.

Fuentes, J., and Coauthors, 2000: Biogenic hydrocarbons in the atmospheric boundary layer: A review. Bull. Amer. Meteor. Soc., 81, 1537-1575.

Gery, M. W., G. Z. Whitten, J. P. Killus, and M. C. Dodge, 1989: A photochemical kinetics mechanism for urban and regional scale computer modeling. J. Geophys. Res., 94, 12 925-12 956.

Guenther, A., P. Zimmerman, and M. Wildermuth, 1994: Natural volatile organic compound emissions rate estimates for U.S. woodland landscapes. Atmos. Environ., 28, 1197-1210.

Gustafson, W. I., and L. R. Leung, 2007: Regional downscaling for air quality assessment: A reasonable proposition? Bull. Amer. Meteor. Soc., 88, 1215-1227.

Hogrefe, C., and Coauthors, 2004a: Simulating regionalscale ozone climatology over the eastern United States: Model evaluation results. Atmos. Environ., 38, 2627-2638. 
— , and Coauthors, 2004b: Simulating changes in regional air pollution over the eastern United States due to changes in global and regional climate and emissions. J. Geophys. Res., 109, D22301, doi:10.1029/2004JD004690.

Horowitz, L. W., and Coauthors, 2003: A global simulation of tropospheric ozone and related tracers: Description and evaluation of MOZART, version 2. J. Geophys. Res., 108, 4784, doi:10.1029/2002JD002853.

— - and Coauthors, 2007: Observational constraints on the chemistry of isoprene nitrates over the eastern United States. J. Geophys. Res., 112, D12S08, doi:10.1029/2006JD007747.

Huang, H.-C., X.-Z. Liang, K. E. Kunkel, M. Caughey, and A. Williams, 2007: Seasonal simulation of tropospheric ozone over the midwestern and northeastern United States: An application of a coupled regional climate and air quality modeling system. J. Appl. Meteor. Climatol., 46, 945-960.

— - and Coauthors, 2008: Impacts of long-range transport of global pollutants and precursor gases on U.S. air quality under future climatic conditions. J. Geophys. Res., 113, D19307, doi:10.1029/2007JD009469.

Jacob, D. J., and D. A. Winner, 2009: Effect of climate change on air quality. Atmos. Environ., 43, 51-63.

Jerrett, M., and Coauthors, 2009: Long-term ozone exposure and mortality. N. Engl. J. Med., 360, 1085-1095.

Kunkel, K. E., and Coauthors, 2007: Sensitivity of future ozone concentrations in the northeast USA to regional climate change. Mitigation Adapt. Strategies Global Change, 13, 597-606.

Langner, J., R. Bergstrom, and V. Foltescu, 2005: Impact of climate change on surface ozone and deposition of sulphur and nitrogen in Europe. Atmos. Environ., 39, 1129-1141.

Leibensperger, E. M., L. J. Mickley, and D. J. Jacob, 2008: Sensitivity of U.S. air quality to mid-latitude cyclone frequency and implications of 1980-2006 climate change. Atmos. Chem. Phys., 8, 7075-7086.

Leung, L. R., and W. I. Gustafson, 2005: Potential regional climate change and implications to U.S. air quality. Geophys. Res. Lett., 32, L16711, doi:10.1029/2005GL022911.

Liang, X.-Z., L. Li, A. Dai, and K. E. Kunkel, 2004a: Regional climate model simulation of summer precipitation diurnal cycle over the United States. Geophys. Res. Lett., 31, L24208, doi:10.1029/2004GL021054.

—,- , K. E. Kunkel, M. Ting, and J. X. L. Wang, 2004b: Regional climate model simulation of U.S. precipitation during 1982-2002. Part I: Annual cycle. J. Climate, 17, 3510-3529.

_ , J. Pan, J. Zhu, K. E. Kunkel, J. X. L. Wang, and A. Dai, 2006: Regional climate model downscaling of the U.S. summer climate and future change. J. Geophys. Res., 111, D10108, doi:10.1029/2005JD006685.

Liao, K.-J., E. Tagaris, K. Manomaiphiboon, S. L. Napelenok, J.-H. Woo, S. He, P. Amar, and A. G. Russell, 2007: Sensitivities of ozone and fine particulate matter formation to emissions under the impact of potential future climate change. Environ. Sci. Technol., 41, 8355-8361, doi:10.1021/es070998z.

— — _ _ - C. Wang, J.-H. Woo, S. He, P. Amar, and A. G. Russell, 2009: Climate impacts on air quality response to controls: Not such an uncertain future. Atmos. Chem. Phys., 9, 865-878.

Lin, J.-T. K. O. Patten, K. Hayhoe, X.-Z. Liang, and D. J. Wuebbles, 2008: Effects of future climate and biogenic emissions changes on surface ozone over the United States and China. J. Appl. Meteor. Climatol., 47, 1888-1909.

Lynn, B. H., R. Healy, and L. M. Druyan, 2007: An analysis of the potential for extreme temperature change based on observations and model simulations. J. Climate, 20, 1539-1554.

Meleux, F., F. Solmon, and F. Giorgi, 2007: Increase in European summer ozone amounts due to climate change. Atmos. Environ., 41, 7577-7587.

Mickley, L. J., D. J. Jacob, B. D. Field, and D. Rind, 2004: Effects of future climate change on regional air pollution episodes in the United States. Geophys. Res. Lett., 31, L24103, doi:10.1029/2004GL021216.

Morris, R. E., P. D. Guthrie, and C. A. Knopes, 1995: Photochemical modeling analysis under global warming conditions. Proc. 88th Air and Waste Management Association Annual Meeting and Exhibition, Pittsburgh, PA, Air and Waste Management Association, Paper 95-WP-74B.02.

Murazaki, K., and P. Hess, 2006: How does climate change contribute to surface ozone change over the United States? J. Geophys. Res., 11, D05301, doi:10.1029/2005JD005873.

Nakicenovic, N., and Coauthors, 2000: Special Report on Emissions Scenarios. Cambridge University Press, Cambridge, 599 pp.

Nolte, C. G., A. B. Gilliland, C. Hogrefe, and L. J. Mickley, 2008: Linking global to regional models to assess future climate impacts on surface ozone levels in the United States. J. Geophys. Res., 113, D14307, doi:10.1029/2007JD008497.

NRC, 1991: Rethinking the Ozone Problem in Urban and Regional Air Pollution. National Academy Press, 500 pp. —-, 2001: Global Air Quality: An Imperative for LongTerm Observational Strategies. National Academy Press, $41 \mathrm{pp}$.

_, 2004: Air Quality Management in the United States. National Academies Press, 401 pp. 
Pierce, T., C. Geron, L. Bender, R. Dennis, G. Tonnesen, and A. Guenther, 1998: Influence of increased isoprene emissions on regional ozone modeling. $J$. Geophys. Res., 103, 25 611-25 629.

Purves, D. W., J. P. Caspersen, P. R. Moorcroft, G. C. Hurtt, and S. W. Pacala, 2004: Human-induced changes in US biogenic volatile organic compound emissions: Evidence from long-term forest inventory data. Global Change Biol., 10, 1737-1755, doi:10.111/ j.1365-2486.2004.00844.x.

Racherla, P. N., and P. J. Adams, 2006: Sensitivity of global tropospheric ozone and fine particulate matter concentrations to climate change. J. Geophys. Res., 111, D24103, doi:10.1029/2005JD006939.

— to climate change over the Eastern United States. Atmos. Chem. Phys., 8, 871-885.

Roselle, S., T. Pierce, and K. Schere, 1991: The sensitivity of regional ozone modeling to biogenic hydrocarbons. J. Geophys. Res., 96, 7341-7394.

Russell, G. L., J. R. Miller, and D. Rind, 1995: A coupled atmosphere-ocean model for transient climate change studies. Atmos.-Ocean, 33, 683-730.

Sillman, S., and P. J. Samson, 1995: Impact of temperature on oxidant photochemistry in urban, polluted rural and remote environments. J. Geophys. Res., 100, 11 497-11508.

Solomon, S., D. Quin, M. Manning, M. Marquis, K. Averyt, M. M. B. Tignor, H. L. Miller Jr., and Z. Chen, Eds., 2007: Climate Change 2007: The Physical Science Basis. Cambridge University Press, 996 pp.

Steiner, A. L., S. Tonse, R. C. Cohen, A. H. Goldstein, and R. A. Harley, 2006: Influence of future climate and emissions on regional air quality in California. J. Geophys. Res., 111, D18303, doi:10.1029/2005JD006935.

Stevenson, D. S., and Coauthors, 2006: Multimodel ensemble simulations of present-day and near-future tropospheric ozone. J. Geophys. Res., 111, D08301, doi:10.1029/2005JD006338.

Stockwell, W. R., P. Middleton, J. S. Chang, and X. Tang, 1990: The second generation Regional Acid Deposition Model chemical mechanism for regional air quality modeling. J. Geophys. Res., 95, $16343-16367$.

Szopa, S., and D. A. Hauglustaine, 2007: Relative impacts of worldwide tropospheric ozone changes and regional emission modifications on European surface-ozone levels. C. R. Geosci., 339, 96 pp.

Tao, Z., A. Williams, H.-C. Huang, M. Caughey, and X.-Z. Liang, 2007: Sensitivity of U.S. surface ozone to future emissions and climate changes. Geophys. Res. Lett., 34, L08811, doi:10.1029/2007GL029455.
,,,---- , and,- 2008 : Sensitivity of surface ozone simulation to cumulus parameterization. J. Appl. Meteor. Climatol., 47, 1456-1466.

Targaris, E., K. Manomaiphiboon, K.-J. Liao, L. R. Leung, J.-H. Woo, S. He, P. Amar, and A. G. Russell, 2007: Impacts of global climate change and emissions on regional ozone and fine particulate matter concentrations over the United States. J. Geophys. Res., 112, D14312, doi:10.1029/2006JD008262.

Thompson, M. L., J. Reynolds, L. H. Cox, P. Guttorp, and P. D. Sampson, 2001: Review of statistical methods for the meteorological adjustment of tropospheric ozone. Atmos. Environ., 35, 617-30.

U.S. EPA, 1989: The potential effects of global climate change on the United States. EPA EPA-230-05-89050, 457 pp.

_ 1999: Guideline for developing an ozone forecasting system. U.S. EPA EPA-454/R-99-009, 88 pp.

- 2 2008: National air quality: Status and trends through 2007. U.S. EPA EPA-454/R-08-06, 48 pp.

- 2009: Assessment of the impacts of global change on regional U.S. air quality: A synthesis of climate change impacts on ground-level ozone. U.S. EPA EPA/600/R-07/094F, 131 pp. [Available online at www.epa.gov/ncea.]

Woo, J.-H., S. He, E. Tagaris, K. J. Liao, K. Manomaiphiboon, P. Amar, and A. G. Russell, 2008: Development of North American emission inventories for air quality modeling under climate change. J. Air Waste Manage. Assoc., 58, 1483-1494.

Wu, S., L. J. Mickley, D. J. Jacob, J. A. Logan, R. M. Yantosca, and D. Rind, 2007: Why are there large differences between models in global budgets of tropospheric ozone? J. Geophys. Res., 112, D05302, doi:10.1029/2006JD007801.

,,-- E. M. Leibensperger, D. J. Jacob, D. Rind, and D. G. Streets, 2008a: Effects of 2000-2050 global change on ozone air quality in the United States. J. Geophys. Res., 113, D06302, doi:10.1029/2007JD008917. - _ - D. J. Jacob, D. Rind, and D. G. Streets, 2008b: Effects of 2000-2050 changes in climate and emissions on global tropospheric ozone and the policy-relevant background surface ozone in the United States. J. Geophys. Res., 113, D18312, doi:10.1029/2007JD009639.

Zeng, G., J. A. Pyle, and P. J. Young, 2008: Impact of climate change on tropospheric ozone and its global budgets. Atmos. Chem. Phys., 8, 369-387.

Zhang, Y., X.-M. Hu, L. R. Leung, and W. I. Gustafson, 2008: Impacts of regional climate change on biogenic emissions and air quality. J. Geophys. Res., 113, D18310, doi:10.1029/2008JD009965. 